\title{
Modern incursions of tropical Radiolaria into the Arctic Ocean
}

\author{
KJELL R. BJØRKLUND ${ }^{1}$, SVETLANA B. KRUGLIKOVA ${ }^{2} \&$ O. ROGER ANDERSON ${ }^{3 *}$ \\ ${ }^{1}$ Natural History Museum, Department of Geology, University of Oslo, PO Box 1172 Blindern, 0318 Oslo, Norway. \\ ${ }^{2}$ P.P. Shirshov Institute of Oceanology, Russian Academy of Sciences, Nakhimovsky Prospect 36, 117883 Moscow, Russia. \\ ${ }^{3}$ Biology and Paleo Environment, Lamont-Doherty Earth Observatory of Columbia University, Palisades, New York 10964, USA. \\ *Corresponding author (e-mail: ora@LDEO.columbia.edu)
}

\begin{abstract}
Plankton samples obtained by the Norwegian Polar Institute (August, 2010) in an area north of Svalbard contained an unusual abundance of tropical and subtropical radiolarian taxa (98 in 145 total observed taxa), not typically found at these high latitudes. A detailed analysis of the composition and abundance of these Radiolaria suggests that a pulse of warm Atlantic water entered the Norwegian Sea and finally entered into the Arctic Ocean, where evidence of both juvenile and adult forms suggests they may have established viable populations. Among radiolarians in general, this may be a good example of ecotypic plasticity. Radiolaria, with their high species number and characteristic morphology, can serve as a useful monitoring tool for pulses of warm water into the Arctic Ocean. Further analyses should be followed up in future years to monitor the fate of these unique plankton assemblages and to determine variation in northward distribution and possible penetration into the polar basin. The fate of this tropical fauna (persistence, disappearance, or genetic intermingling with existing taxa) is presently unknown. The current event may not be unique, nor a consequence of global warming, because analyses of sediment samples suggest that several natural pulses of warm water of this kind occurred in the prior century and, indeed, there may be more in years to come. J. Micropalaeontol. 31(2): 139-158, July 2012.
\end{abstract}

KEYWORDS: arctic and tropical radiolarians, biogeography, ocean currents, plankton ecology, water mass marker biota

\section{INTRODUCTION}

The Arctic Ocean is an area of increasing interest due to the scientific and political discussions about a warming ocean, whether this is on a global, regional or local scale. Polycystina, a part of the group formerly called Radiolaria, are single-celled protozoans. Radiolarian taxonomy is presently in a state of considerable reformation. Molecular genetic analyses have shown that the classical Haeckelian higher-rank taxonomy is not acceptable, and will no doubt undergo even further improvements as additional molecular phylogenetic data become available. Currently the radiolarian groups that we examine in this study will be assigned to the orders Collodaria, Spumellaria and Nassellaria, collectively called Polycystina (Suzuki \& Aita, 2011).

Radiolarians are microscopic in size and possess unusual, beautiful siliceous tests, between $50 \mu \mathrm{m}$ and $200 \mu \mathrm{m}$ in size. Radiolarians are widely distributed in the whole World Ocean, with the exception of the White, Baltic, Caspian and Black seas. Recently, we have studied the radiolarian fauna in the bottom sediments and some plankton samples from the Arctic Ocean (Kruglikova, 1988; 1989; Bjørklund \& Kruglikova, 2003; Kruglikova et al., 2009, amongst others). Special attention was given to the distribution of species, composition of assemblages, endemism and speciation. These studies provide the ideal background to draw ecological inferences from radiolarian species distributions. It has now become evident that the various oceanic areas are characterized by their own specific species associations. This is not only the case for species distributions, so-called 'low rank taxa', but equally for the distribution of 'high rank taxa', including families and genera (Bjørklund \& Kruglikova, 2003; Kruglikova, 2009; 2011). For example, it would not be likely, nor would we expect, to find a high diversity of some members of the Collodaria, Spumellaria (e.g. Spongodiscoidea and Artiscinae) and
Nassellaria (e.g. Spyrida) in the Arctic Ocean, as these taxa occur more abundantly elsewhere.

Riedel (1958), Petrushevskaya (1967) and Kruglikova (1969) stated, and Bjørklund \& Kruglikova (2003) confirmed, that many groups of polycystines (Panartidae, Zigartidae, Euchithoniidae, Pterocorydinae, Carpocaniidae, Artiscinae and Phacodiscidae) have never been found in sediment deposits at high latitudes. We can, therefore, reliably predict which faunal associations or species composition are likely to occur in a given geographical area or environment. The Arctic province (Fram Strait, Barents Sea, Kara Sea, Laptev Sea, Chukchi Sea and the central Arctic Basin) is characterized by about 60 radiolarian species. We showed previously that the shallow Arctic marginal sea sediments (Iceland, Barents and Chukchi seas) have a strong dominance of Cannobotryidae $(79 \%, 77 \%$ and $74 \%$, respectively), while the deep Arctic Ocean basins (Nansen, Amundsen and Makarov basins) have a dominance of Actinommidae (90\%, 70\% and 75\%, respectively). In terms of biogeography, it is also important to mention that the arctic polycystine radiolarian species have a very strong affinity with those listed for the Norwegian Sea. By inference, we suggest that the Norwegian Sea supplies the Arctic Ocean with radiolarian faunal elements that can live, thrive and reproduce there (e.g. Kruglikova et al., 2009).

Recently, we analysed seven samples of living radiolarians from the water column collected north of Spitsbergen during August 2010 (Fig. 1). We unexpectedly found tropical or subtropical species that do not normally inhabit these arctic environments. We define 'tropical' as species occurring in lower latitude locales other than the boreal and arctic region, in other words species that through advection have reached other faunal provinces. They were present in all samples, but especially in two (Stations R5 and 6b, Fig. 1, Table 1). Out of the 145 taxa observed in the 


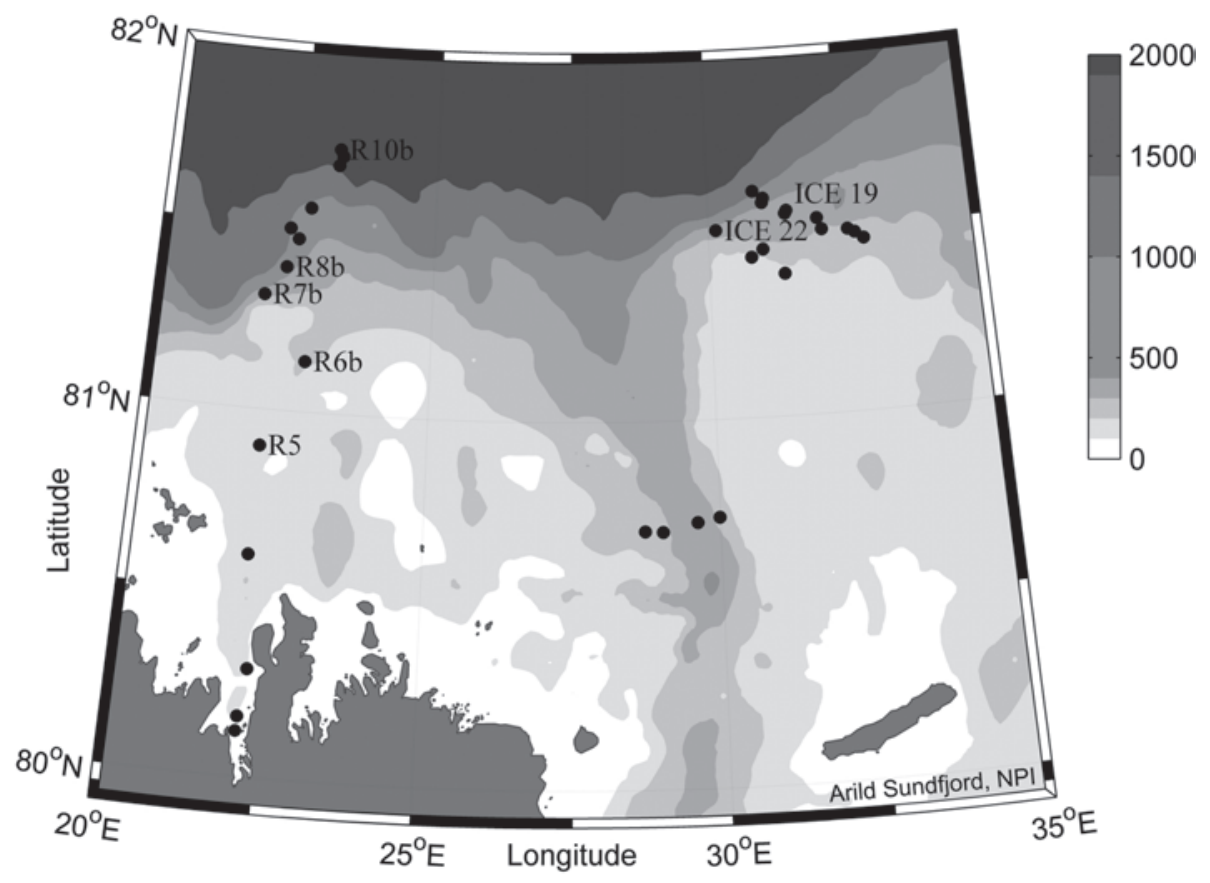

Fig. 1. Map of the plankton sample stations and geographical coordinates. Designed by Dr Arild Sundfjord. See also Table 1.

Table 1. Plankton sampling stations, geographical coordinates and related sampling parameters for collections at Svalbard during August 2010.

\begin{tabular}{|c|c|c|c|c|c|c|c|c|}
\hline Station & Lat ${ }^{\circ} \mathrm{N}$ & Long ${ }^{\circ} \mathrm{E}$ & $\begin{array}{l}\text { Bottom depth } \\
\text { (m) }\end{array}$ & $\begin{array}{l}\text { Sampling date } \\
\text { (UTC) }\end{array}$ & $\begin{array}{l}\text { PMO slide } \\
\text { numbers }\end{array}$ & Gear (net; $\mu \mathrm{m}$ ) & $\begin{array}{l}\text { Sampling depth } \\
\text { (m) from }\end{array}$ & CTD nr \\
\hline R5 & 80.54 & 22.09 & 128 & $19 / 08 / 2010$ & 223.393 & 63 & $120-0$ & st012 \\
\hline $\mathrm{R} 7 \mathrm{~b}$ & 81.18 & 21.58 & 368 & $21 / 08 / 2010$ & 223.395 & 63 & $315-0$ & st016 \\
\hline $\mathrm{R} 8 \mathrm{~b}$ & 81.23 & 22.21 & 508 & $21 / 08 / 2010$ & 223.396 & 63 & $470-0$ & st019 \\
\hline R10b & 81.43 & 23.1 & 2798 & $24 / 08 / 2010$ & 223.397 & 63 & $300-0$ & st028 \\
\hline
\end{tabular}

At St Ice19, CTD st038 was used instead of st036. PMO slide numbers are type collection repository numbers (Natural History Museum, University of Oslo); see also references in Plates 1-7.

samples, 50 have been identified to species that are normally found only at more southerly latitudes, while some are restricted only to the tropical or subtropical regions In addition we have also identified 48 taxa to the level of genus. These are taxa that we have never seen in these high latitudes, but were seen only in North Atlantic warm-water domains. The recent occurrence of these warm-water faunal elements in high latitude environments should, therefore, be of great importance with respect to the ongoing discussion of a changing climate. Does our finding provide additional scientific evidence for a warming of the Arctic Ocean, or not?

Different oceanic water masses in the North Atlantic have long been known as being characterized by their specific microflora and microfauna (Cleve, 1901; 1903). Cleve (1903, p. 7) stated that 'The seasonal distribution of Atlantic Plankton-organisms, will fully prove that each current-system carries its own planktonflora and fauna'. Above the Newfoundland Banks he reported that tropical and arctic species frequently co-occur in the same haul.
There are two ways of studying the global distribution of polycystine radiolarians, either by determining their occurrence in the top layer of ocean bottom sediments or in plankton net samples from the water column. Those collected in the net samples are living organisms and thus tell us very precisely about the faunal association and composition at the site during the time of sampling. The radiolarians collected from the sea bottom (top $1 \mathrm{~cm}$ ) are tests of species that once lived in the water column above the site, but represent an accumulation of dead remains spanning several years/decades, thus making it difficult to pinpoint their exact origin and time of occurrence. In addition, these assemblages can be strongly influenced by dissolution, i.e. differential loss of tests of some species due to the silica dissolving in the seawater (Johnson, 1974). Our new plankton material is, therefore, an important contribution to the understanding of both the biocoenosis (living assemblages) and the thanatocoenosis (assemblages based on skeletal remains) of Radiolaria at this Arctic locale. Moreover, the tropical drift fauna will also provide information 


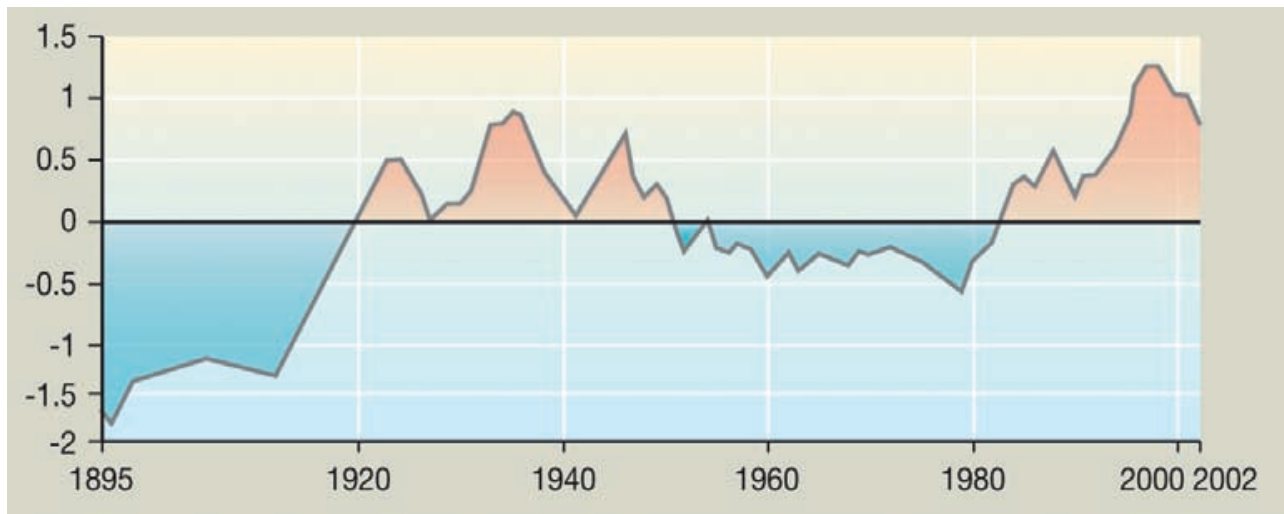

Fig. 2. Temperature anomalies $\left({ }^{\circ} \mathrm{C}\right)$ of the intermediate Atlantic Water in the Arctic Ocean, 1895-2002 (Polyakov et al., 2005). Reprinted with permission, UNEP/GRID-Arendal (http://maps.grida.no/go/graphic/temperature-anomalies-of-the-intermediate-atlantic-water-in-arctic-ocean). Designed by Laura Margueritte.

Table 2. Species data tabulated in relation to stations.

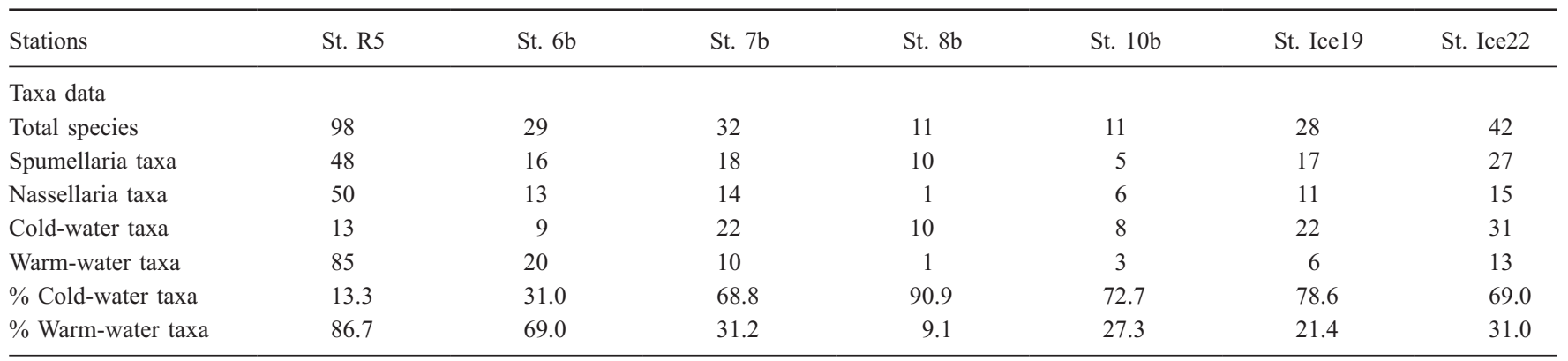

about changes in the water masses in which they are living. An elucidation of these topics will be the main goal of this paper.

\section{MATERIAL AND METHODS}

The Norwegian Polar Institute (NPI) Centre for Ice, Climate and Ecosystems (ICE) ran a plankton net sampling programme during an expedition with $\mathrm{R} / \mathrm{V}$ Lance to the area north of Svalbard (16-29 August 2010). Seven stations were sampled with a $63 \mu \mathrm{m}$ Juday net (Fig. 1, Table 1). Living radiolarians generally possess a large amount of protoplasm outside of the siliceous test and are strongly adhesive. Consequently, a plankton net with a 63 $\mu \mathrm{m}$-mesh pore size efficiently collects radiolarians with small tests, such as plagiancathids (see Pl. 4, figs 1-13). In other words, small, dead radiolarians without protoplasm would likely pass through the plankton net; and we can potentially regard small radiolarians less than $63 \mu \mathrm{m}$ in size as living organisms. The plankton samples were taken from close to the bottom up to the surface at the shallow stations, while at the deeper stations, only the upper $300 \mathrm{~m}$ were sampled. Information on the water quality (e.g. temperature, salinity and oxygen) was collected at the same time at each site. Sample material was sieved over a $45 \mu \mathrm{m}$ screen, then treated with $10 \% \mathrm{H}_{2} \mathrm{O}_{2}$ and $\mathrm{HCl}$. Radiolarian slides were then prepared from this residue following standard techniques and using Canada Balsam as mounting medium. See Swanberg \& Bjørklund (1986) for further details on sample and slide preparation. The radiolarians were examined using a Zeiss Axiophot microscope, objectives
$10 \times$ and $20 \times$, oculars $10 \times$ and an optovar with magnifications of $1.25 \times, 1.6 \times$ and $2.0 \times$. Photomicrographs were made with a Mitsubishi video camera. The slides from each station were given a PMO number (PMO 223.393) and subnumbers (.../1), according to how many slides were made from each sample, as entered in the plate legends. All slides with PMO numbers are stored in the palaeontological type collection at the Natural History Museum, University of Oslo (formerly PMO - Paleontological Museum Oslo). Slides identified as 'St. R5 slide V' are in Dr Svetlana Kruglikova's private collection.

\section{RESULTS}

\section{The tropical polycystine fauna}

Our results on the tropical fauna are summarized in Tables 2 and 3, and Plates 1-7. So far we have observed in total 145 different polycystine forms, 63 spumellarians and 82 nassellarians. Among spherical polycystines, the order Collodaria are especially abundant in the tropics-subtropics and in tropical upwelling areas (Kruglikova, 2011), including typical examples such as Siphonosphaera cyatina (Pl. 1, fig. 2), Collosphaera macropora (Pl. 1, fig. 3), C. huxleyi (Pl. 1, fig. 4) and Acrosphaera flammabunda (Pl. 1, fig. 5). These species have never been observed previously this far north.

In the Arctic Ocean, our prior observations among the family Spongodiscidae included only Spongotrochus glacialis (P1. 3, fig. 4). In our new material, we recorded 12 additional forms of tropical origin, and three are illustrated herein: Spongaster tetras 
Table 3. Representative list of warm-water radiolarians.

\section{Collodaria}

Acrosphaera flammabunda (Haeckel) Popofsky, 1917

*Collosphaera huxleyi Haeckel, 1887

*Collosphaera macropora Popofsky, 1917

*Collosphaera tuberosa Haeckel, 1887

Otosphaera auriculata Haeckel, 1887

Siphonosphaera cyatina Haeckel, 1887

*Sphaerozoum punctatum (Meyen) Müller, 1858a

*Collosphaera sp. Haeckel, 1887

\section{Spumellaria}

Amphirhopalum ypsilon Haeckel, 1887

*Dictyocoryne truncatum (Ehrenberg) Haeckel, 1887

*Didymocyrtis tetrathalamus (Haeckel) Nigrini \& Moore, 1979

Dipylissa bensoni? Dumitrica, 1988

*Euchitonia elegans Ehrenberg, 1860

Euchitonia furcata? Ehrenberg, 1872

Larcospira quadrangula Haeckel, 1887

Plegmosphaera sp.

Pylolena armata Haeckel, 1887

Sethodiscus micrococcus

*Spongaster tetras tetras Ehrenberg, 1860

Spongaster tetras Ehrenberg, 1860 irregularis Nigrini, 1967

Spongobrachium sp. aff. S. ellipticum Haeckel, 1881 sensu Renz, 1976;

P1. 3, fig. 5

Spongodiscus resurgens? Ehrenberg, 1854

Stylodictya micromma (Harting) Kruglikova, 1977

Tetrapyle octacantha $=T$. octopyle? Müller, $1858 \mathrm{~b}$

Tetrapyle quadriloba Haeckel, 1887

\section{Nassellaria}

Amphispyris reticulate Ehrenberg, 1872

Arachnocorallium calvata Petrushevskya, 1971

Arachnocorys pentacantha Popofsky, 1913

Botryocyrtis scutum Harting, 1863

Botryopyle dictyocephalus Haeckel, 1887

Carpocanium obliqua (Haeckel, 1887) Petrushevskaya, 1971

Eucyrtidium acuminatum Ehrenberg, 1844

Eucyrtidium anomalum Haeckel, 1887

Lithocircus annularis Müller, 1858b

Lophophaena buetschlii Haeckel, 1887

Lophophaena hispida Ehrenberg, 1872

Neosemantis distephanus (Haeckel) Popofsky, 1913

Nephrodictyum renilla? Haeckel, 1887

Plagiacantha $\mathrm{sp}$.

Pseudocubus obeliscus Haeckel, 1887

*Pterocanium praetextum praetextum Ehrenberg, 1872

Pterocorys macroceras (Popofsky) Petrushevskaya, 1971

Pterocorys zancleus (Müller) Petrushevskaya, 1971

* Spyrida spp.

Tetraplecta pinigera Haeckel, 1887

Theocorys veneris? Haeckel, 1887

Theocorythium trachelium (Ehrenberg) dianae Nigrini, 1967

Zygocircus rhombus Goll, 1979

Triceraspyris damaecornis = Clathrocircus stapedius Haeckel, 1887

Tricolocampe cylindrica Haeckel, 1887

Trisulcus boldyrae Petrushevskaya, 1971

Zygocircus capulosus Popofsky, 1913

Zygocircus piscicaudatus Popofsky, 1913

Zygocircus productus Haeckel, 1887

*Species with documented algal and/or cyanobacterial symbionts; it is very likely many other nassellarians also have algal symbionts. tetras (Pl. 3, fig. 3), Dictyocoryne sp. (P1. 3, fig. 2) and D. truncatum (P1. 3, fig. 1). Adult specimens of the latter are found with a well-developed patagium between its three arms. The family Porodiscidae is not represented with a high diversity in either the Norwegian Sea or in the Arctic, but single specimens of Stylodictya validispina were observed in the Norwegian Sea and Fram Strait. In our new material, we discovered five new forms, of which only Euchitonia elegans (Pl. 2, fig. 6) has been illustrated. An unquestionable example of Amphirhopalum ypsilon was observed, along with a Stylodictya micromma?, in addition to two juvenile Stylodictya spp.

Members of the family Pyloniidae also have a surprisingly high diversity: six different forms were recognized, mostly from Station R5. However, we were not able to identify these forms to species level, but one Tetrapyle quadriloba (P1. 2, figs 4, 5) is present. None the less, it is clear that they do not belong to the native arctic fauna. We have seen these forms many times in tropical samples as well as documented examples in prior publications (e.g. Popofsky, 1912; Tan \& Su, 1982; Tan \& Chen, 1990; Suzuki et al., 2009). Therefore, we interpret these forms as introduced tropical fauna.

Finally, the Artiscinae are not known outside the tropical-subtropical region, so the abundant occurrence of different growth stages of Didymocyrtis tetrathalamus (Pl. 3, figs 5-7) was a great surprise. Most of the skeletons are represented as juvenile forms (Pl. 3, fig. 7); and only a few well-developed skeletons, with definite polar caps, were observed (Pl. 3, fig. 5).

It is among the nassellarians that we observed the highest number of tropical species. Most predominant is the high number of Spyrida, a group that we observed for the first time in the Arctic Basin. We identified 15 different spyrid morphs, seven of them to the species level, five illustrated herein (Zygocircus piscicaudatus - Pl. 7, fig. 5; Nephrodictyum renilla - Pl. 7, fig. 6; $Z$. productus - P1. 7, fig. 7; Z. capulosus - P1. 7, fig. 8; Lithocircus annularis - P1. 7, fig. 9; and Z. rhombus - Pl. 7, fig. 10). The high diversity of this group in the Arctic Ocean is a puzzle, but probably is evidence for its ecological plasticity.

In the family Pterocoryidae we observed four species Pterocorys macroceras (Pl. 7, fig. 1), P. zancleus (Pl. 7, fig. 3), Theocorythium trachelium dianae (Pl. 7, fig. 2) and Pterocanium praetextum praetextum (P1. 7, fig. 4). The family Carpocaniidae also is largely a warm-water group (Petrushevskaya, 1971, p. 239) and has its highest species diversity in the tropical region. Our observation of Carpocanium obliqua (P1. 6, fig. 8) is the northernmost recording ever. Among the Cannobotryidae, four species were recorded. Of special interest was Botryocyrtis scutum (P1. 6, fig. 11), a very typical equatorial tropical form (Kruglikova, 1969; 1981; Boltovskoy et al., 2010, fig. 21). However, the most typical and abundant Cannobotryiidae is the local Amphimelissa setosa (P1. 6, fig. 12).

The highest number of species is found in the family Plagiacanthidae, with 39 taxa, of which the subfamily Lophophaeninae has 33 identified species. This includes Lophophaena buetschlii (P1. 4, fig. 6) and L. hispida (Pl. 4, fig. 12), both regarded as circumtropical representatives. The subfamily Plagiacanthinae has five identified species, where Tetraplecta pinigera is also a tropical form (Boltovskoy et al., 2010, fig. 97). Phormacantha hystrix (P1. 5, fig. 4), which is represented here with a twin-formed test, is of particular interest. These twin forms 


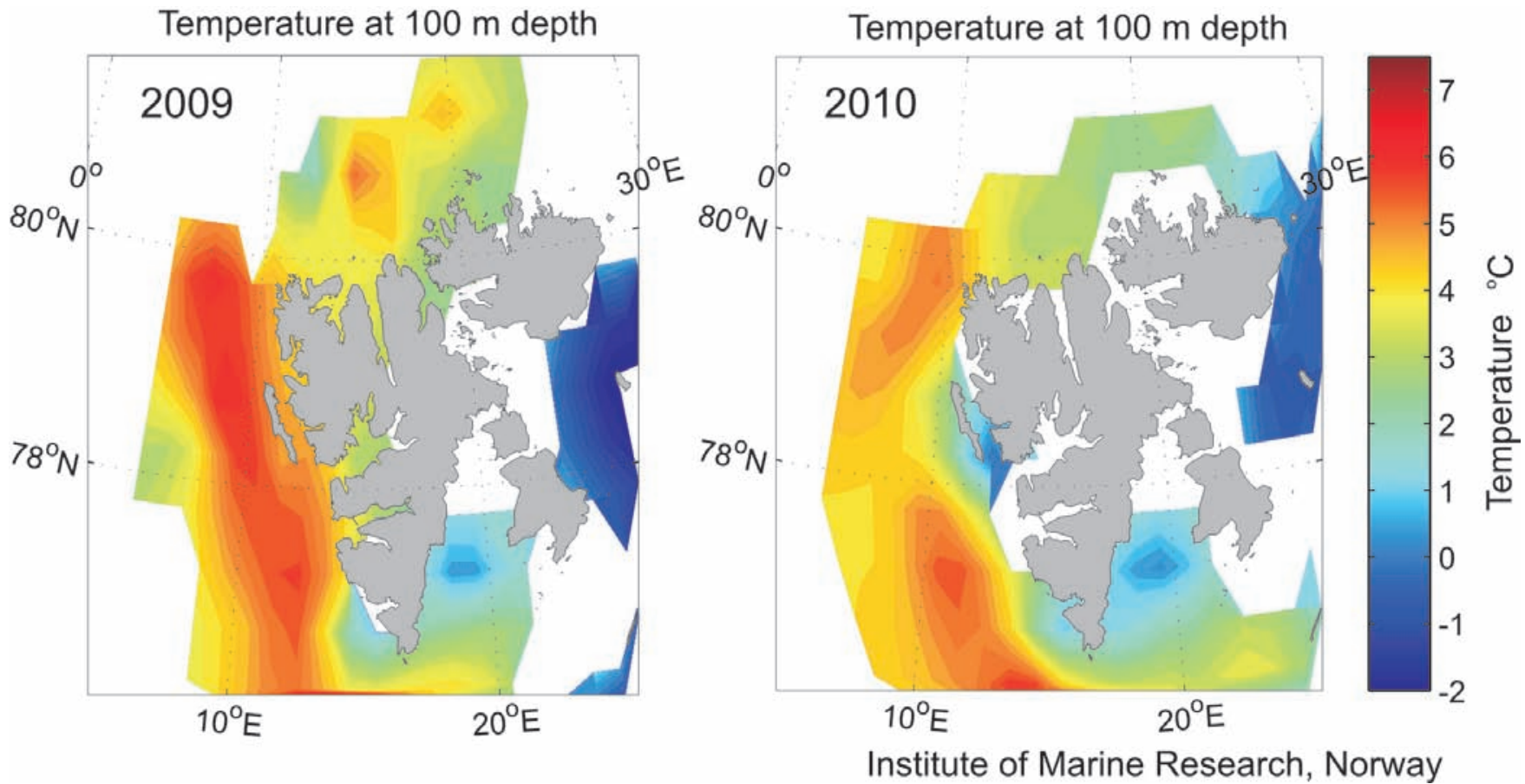

Fig. 3. Maps of temperature (100 m depth) during 2009 and August 2010 (16 August-20 September) sampled by the Norwegian Polar Institute Centre for Ice, Climate and Ecosystems. Courtesy of Dr Randi Ingvaldsen, Institute of Marine Research, Bergen.

are not common in our area and we have observed only one test of this type. Of interest, though, are the frequent findings of twinshaped Actinomma tests in the Japan Sea (Itaki \& Bjørklund, 2007). These authors suggested that the frequent occurrence of the conjoined Actinomma forms in the Japan Sea might be related to its habitat in well-oxygenated, cold, deep water with higher nutrient supplies from the surface. However, it is not known what factors may have contributed to the twin-formed $P$. hystrix.

\section{DISCUSSION}

\section{Arctic Ocean polycystine radiolarians}

With this background, it should be clear that in the Arctic Ocean as well the different water masses can be described not only by their hydrographic properties, but also by their faunal and floral inhabitants (Cleve, 1901; 1903; Gaard et al., 2008; Hátún, et al., 2009). Due to the harsh ice conditions, the Arctic Ocean is not easily accessible to sample and, therefore, very few net samples are available. The reports that we are aware of (Bernstein, 1934; Hülsemann, 1963; Tibbs, 1967; Itaki et al., 2003) only list wellestablished cold-water species. The earliest radiolarian reports from high northern Atlantic areas are from the waters off southwestern Spitsbergen (Cleve, 1900, from the Swedish Expedition in 1898). Also this material, now under revision by KRB to identify Cleve's type specimens, showed that the radiolarian fauna between Svalbard and Greenland is of a local and cold-water nature. No exotic species have been observed in this material. Similarly, Jørgensen (1905) investigated the radiolarian fauna on the west coast of Norway and, in his slides, spanning the time 1898-1900, also under revision (KRB), no exotic radiolarian species were observed, indicating a reduced northward flow of warm Atlantic water towards the end of the nineteenth/beginning of the twentieth century. This is in accordance with Polyakov et al.
(2004), who indicated cold conditions in the Arctic Ocean during the late 1890s (Fig. 2).

The seven new plankton samples from north of Svalbard, collected in August 2010, have now been analysed with respect to polycystine radiolarians. We have so far registered 145 species from these samples, close enough to the Fram Strait to be compared with our previous paper (Bjørklund \& Kruglikova, 2003) where we had a total of 43 species. These were extracted from the sediments just north of the Fram Strait. There is a significant difference in species number between these two sets of samples. This discrepancy is the result of at least two factors: first a totally unexpected introduced exotic radiolarian fauna and, second, that our sediment data also may be hampered by dissolution and, therefore, could be a partial representation of the plankton fauna at the location. To the best of our knowledge 98 out of the 145 taxa identified are of a warm-water origin, or of a tropical-subtropical nature. This means that these 98 taxa have their origin in far more southerly waters. The remaining 48 taxa are all common components of the polycystine radiolarian fauna in the GreenlandIceland-Norwegian Seas complex (Schröder-Ritzrau, 1995; Bjørklund et al., 1998; Dolven et al., 2002; Cortese et al., 2003).

How can we explain the occurrence of this high number of tropical-subtropical radiolarian species this far north? All of our samples typically contain both arctic and tropical polycystine fauna elements. The highest number of both tropical-subtropical species and specimens occurred in our sample from Station R5, where they dominate the fauna. Here, we identified 13/85 (arctic/tropical) taxa. However, from Station R6b the ratio of species dropped to 9/20. In the more northerly stations, the arctic species dominate and the tropical species number declined. For example, the ratio was 22/10 in Station R7b, 10/1 in Station R8b, and 8/3 in Station R10b. The number of species in the easternmost stations are similar to Station 
K. R. Bjørklund et al.
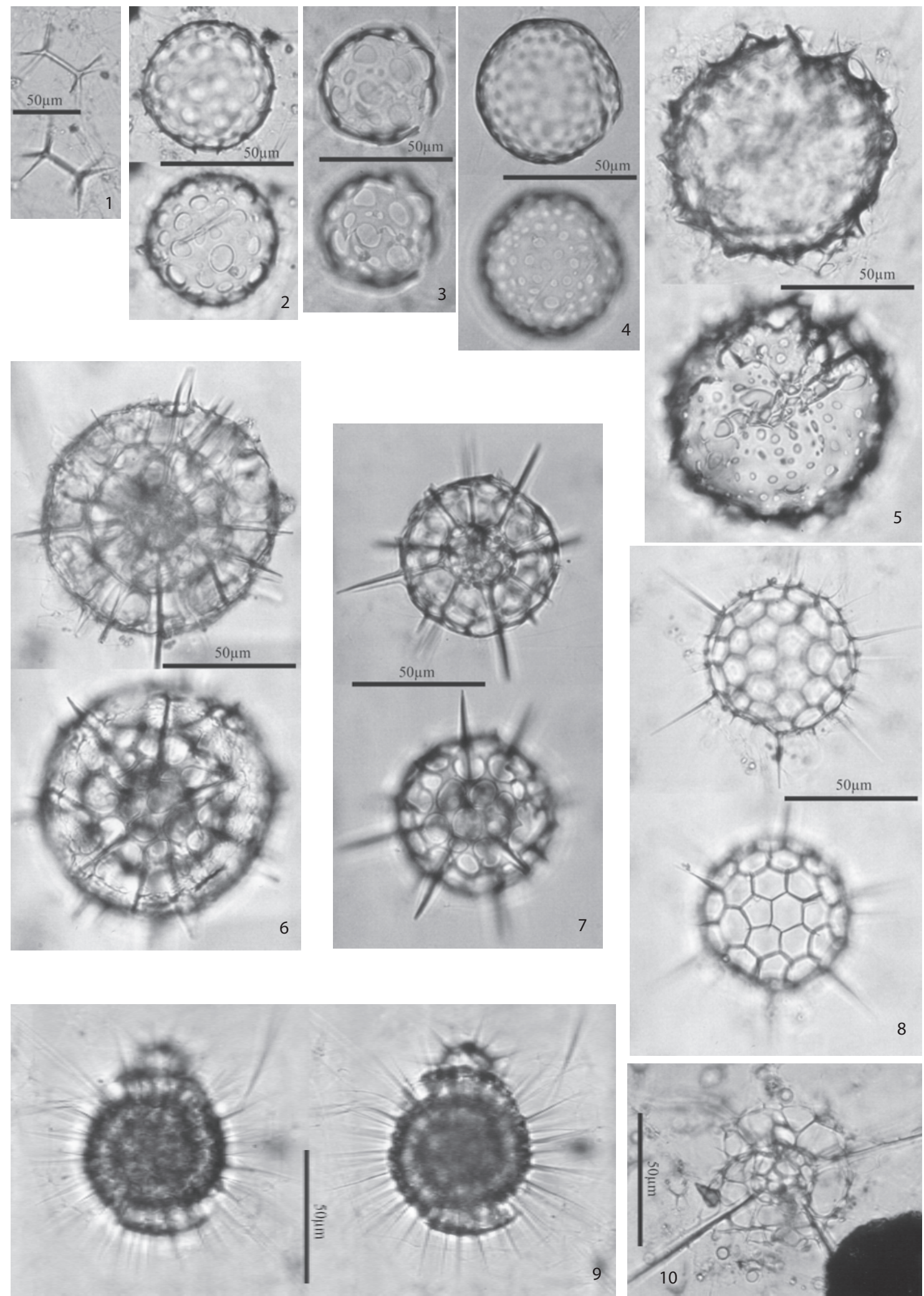

Explanation of Plate 1. figs 1-5. Collodaria: 1, Sphaerozoum punctatum (Meyen), PMO 223.393/3; 2, Siphonosphaera cyatina Haeckel, PMO 223.393/3; 3, Collosphaera macropora Popofsky, PMO 223.393/1; 4, Collosphaera huxleyi Müller, St. 6b slide VIII; 5, Acrosphaera flammabunda (Haeckel), PMO 223.393/3. figs 6-10. Spumellaria: 6, Actinomma boreale (Cleve), PMO 223.397/1; 7, Actinomma leptodermum (Jørgensen), PMO 223.395/1; 8, Arachnosphaera dichotoma Jørgensen, PMO 223.397/1; 9, Lithelius minor Jørgensen, PMO 223.395/1; 10, Rhizoplegma boreale (Cleve), PMO 223.398/1. 

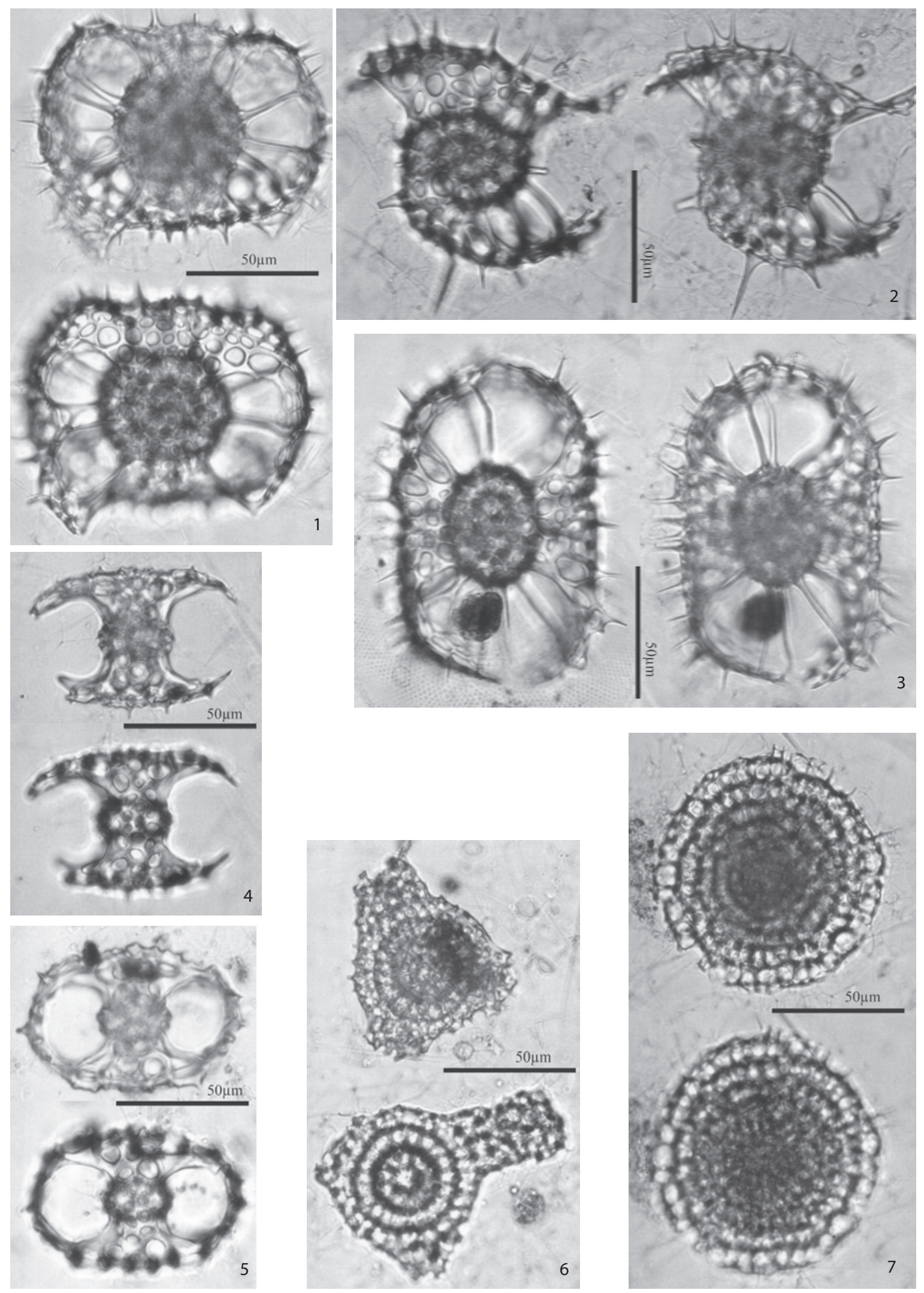

Explanation of Plate 2. figs 1-7. Spumellaria: 1, Tetrapylonium clevei Jørgensen, PMO 223.395/1; 2, 3, Tetrapylonium clevei Jørgensen, both on PMO 223.395/1; 4, Tetrapyle quadriloba Haeckel, PMO 223.393/2; 5, Tetrapyle quadriloba Haeckel, PMO 223.393/1; 6, Euchitonia elegans? (Ehrenberg), top PMO 223.398/1, bottom PMO 223.393/2; 7, Stylodictya? sp., PMO 223.393/2. 

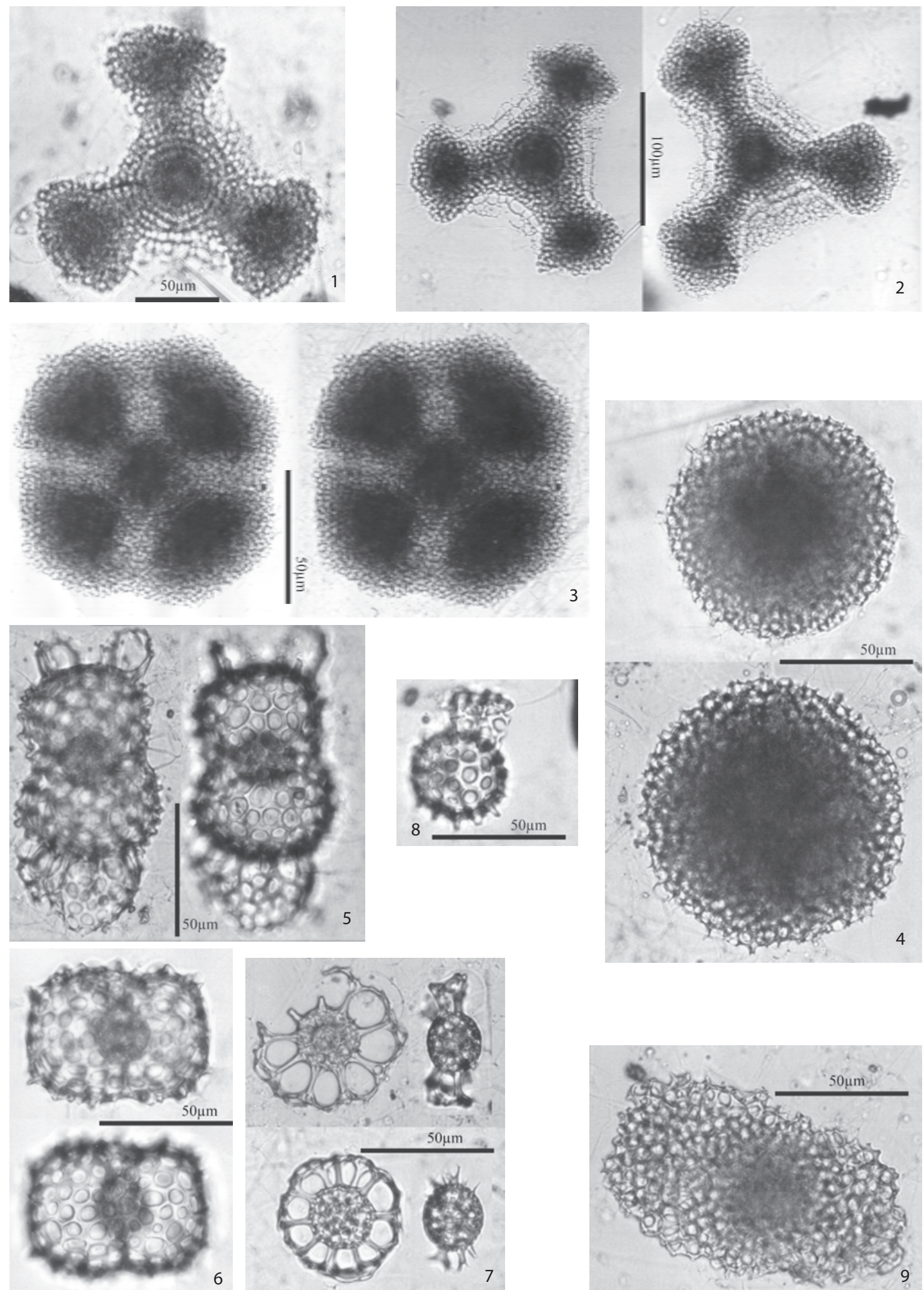

Explanation of Plate 3. figs 1-9. Spumellaria: 1, Dictyocoryne truncatum (Ehrenberg), PMO 223.397/1; 2, Dictyocoryne sp., both on PMO 223.393/3; 3, Spongaster tetras tetras Ehrenberg, PMO 223.394/1; 4, Spongotrochus glacialis Popofsky, top PMO 223.393/2, bottom PMO 223.399/3; 5, Didymocyrtis tetrathalamus (Haeckel), PMO 223.393/3; 6, Didymocyrtis tetrathalamus (Haeckel), PMO 223.393/1; 7, Didymocyrtis tetrathalamus (Haeckel), top left PMO 223.393/1, bottom left PMO 223.393/2; 8, Sethodiscus micrococcus Haeckel juv., PMO 223.393/2; 9, Spongobrachium sp. aff. S. ellipticum Haeckel, sensu Renz, 1976, P1. 3, fig. 5, PMO 223.393/2. 

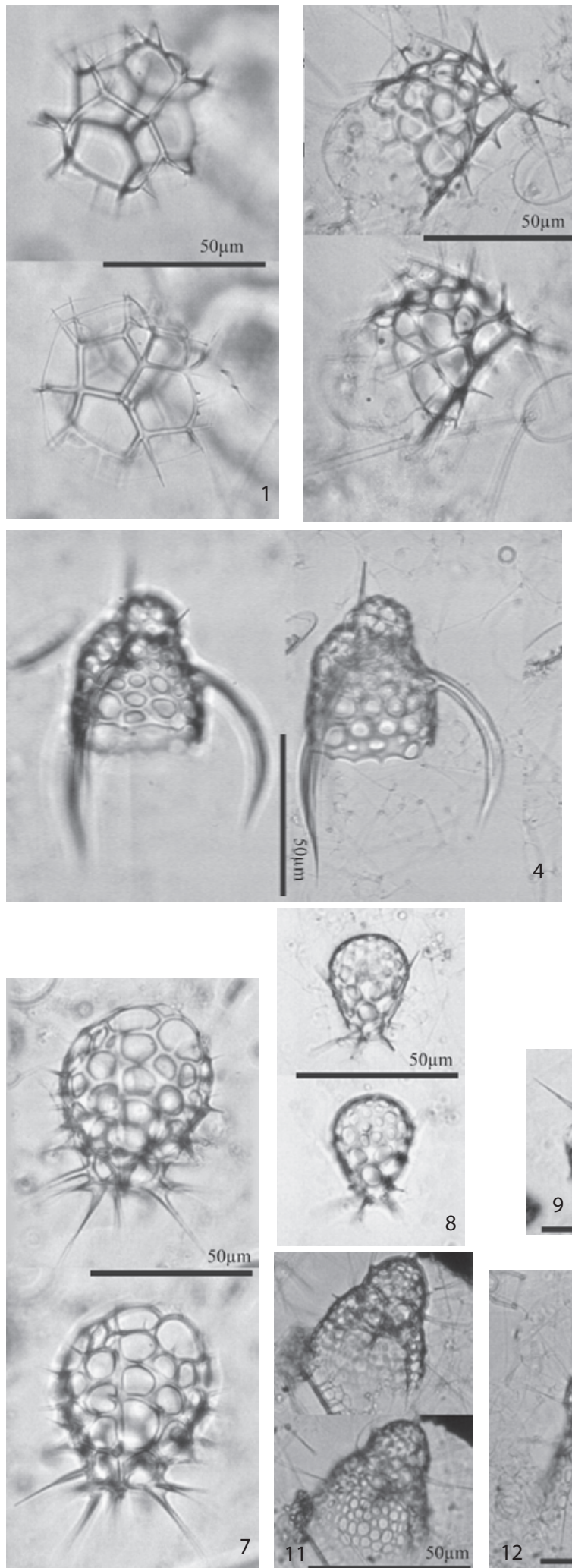

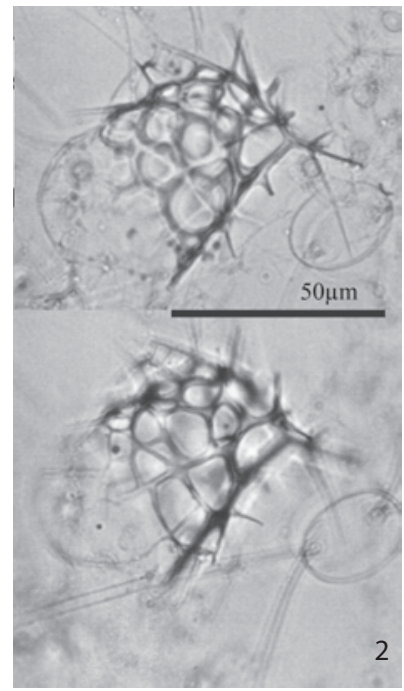

2

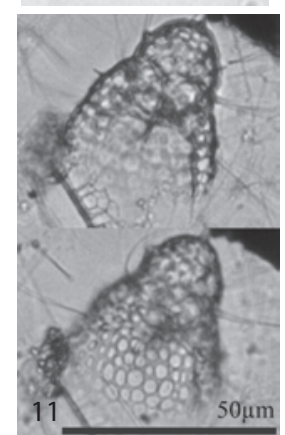

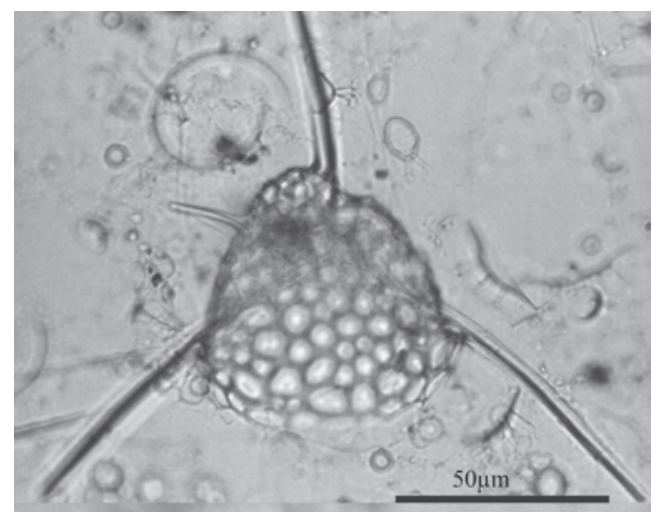
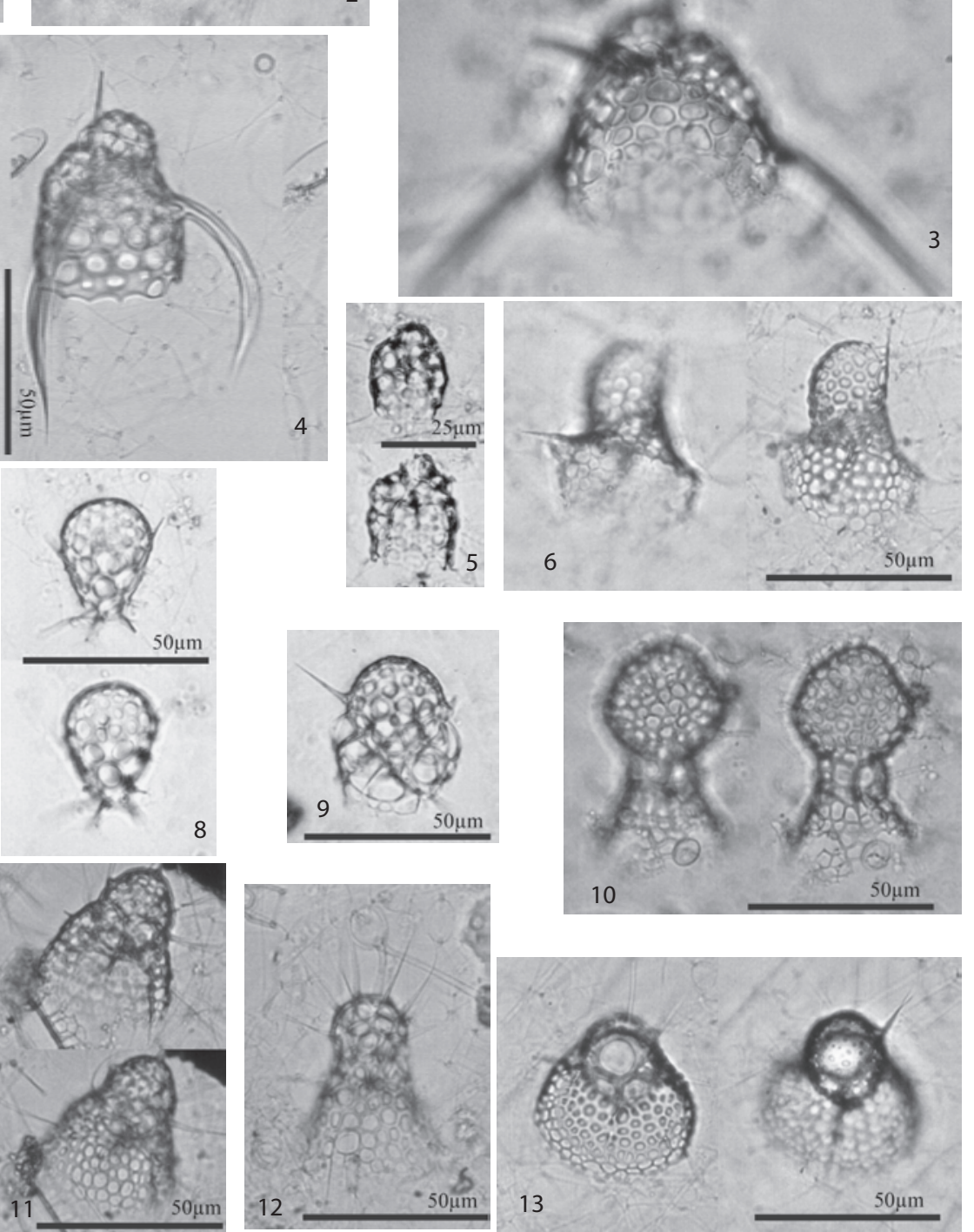

Explanation of Plate 4. figs 1-13. Nassellaria: 1, Protoscenium simplex (Cleve), St. 8b slide VIII; 2, Plectacantha oikiskos Jørgensen, PMO 223.399/3; 3, Pseudodictyophimus clevei (Jørgensen), PMO 223.398/1; 4, Pseudodictyophimus gracilipes (Bailey) bicornis (Ehrenberg), St. 8b slide VII; 5, Lithomelissa hystrix Jørgensen, both on PMO 223.393/2; 6, Lophophaena buetschlii (Haeckel), PMO 223.393/3; 7, Peridium sp.; PMO 223.397/1; 8, 9, Arachnocorallium calvata Petrushevskaya, both on PMO 223.393/1; 10, Lophophaena sp., St. Ice 19 slide 7; 11, Lithomelissa setosa Jørgensen, PMO 223.399/3; 12, Lophophaena hispida (Ehrenberg), PMO 223.395/1; 13, Trisulcus sp., St. 6b slide 7. 

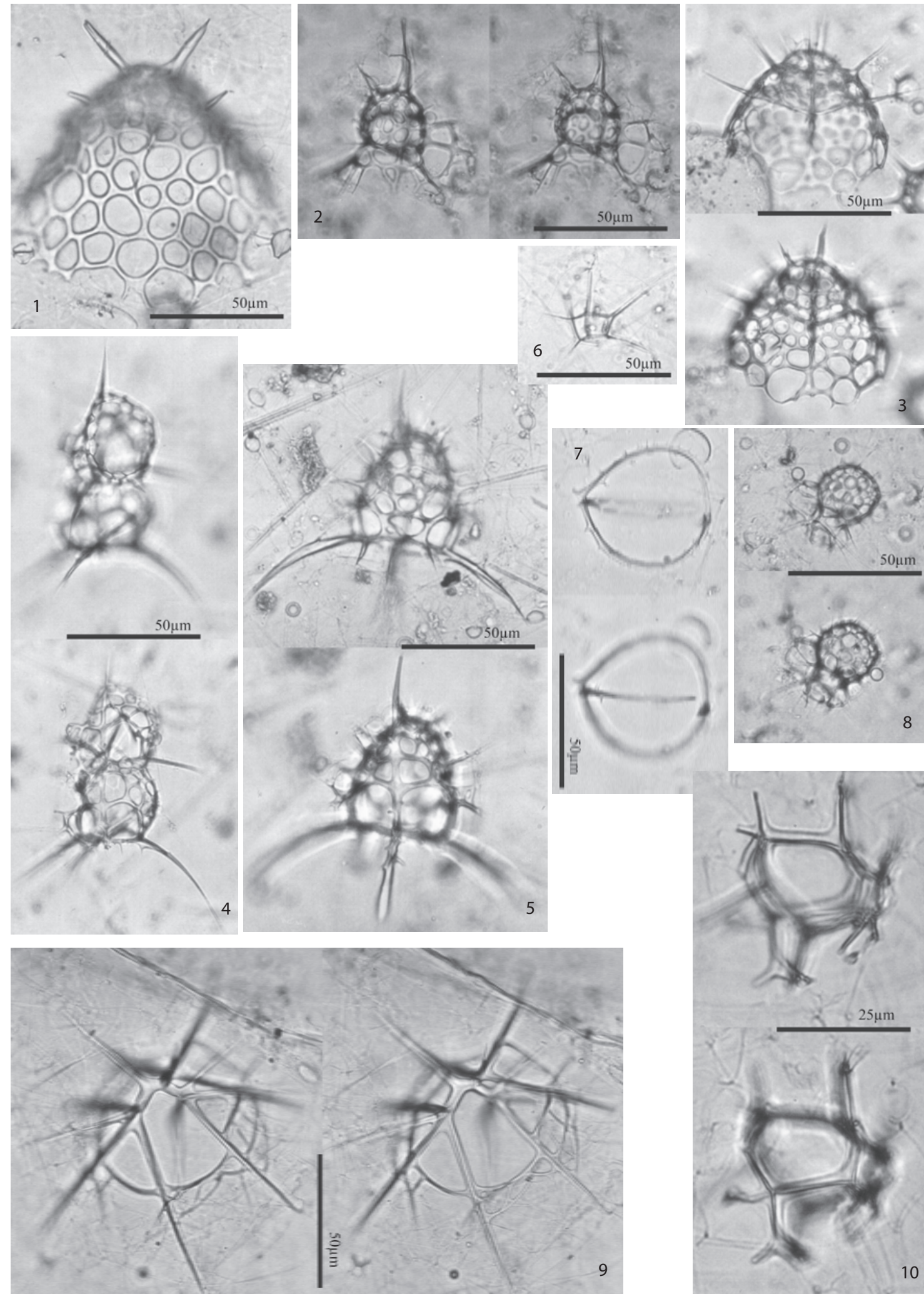

Explanation of Plate 5. figs 1-10. Nassellaria: 1, Ceratocyrtis galeus (Cleve), PMO 223.3936/1; 2, Arachnocorys? sp. (arctic form), PMO 223.398/3; 3, Ceratocyrtis histricosus (Jørgensen), PMO 223.399/1; 4, Phormacantha hystrix Jørgensen, PMO 223.397/1; 5, Phormacantha sp. (arctic form), PMO 223.396/1; 6, Pseudocubus obeliscus Haeckel, PMO 223.393/2; 7, Neosemantis distephanus Popofsky, PMO 223.393/5; 8, Arachnocorys? sp. (arctic form), PMO 223.398/2; 9, Plagiacantha aracnoides (Claparède), St. 6b slide 7; 10, Pseudocubus obeliscus Haeckel, PMO 223.394/1. 

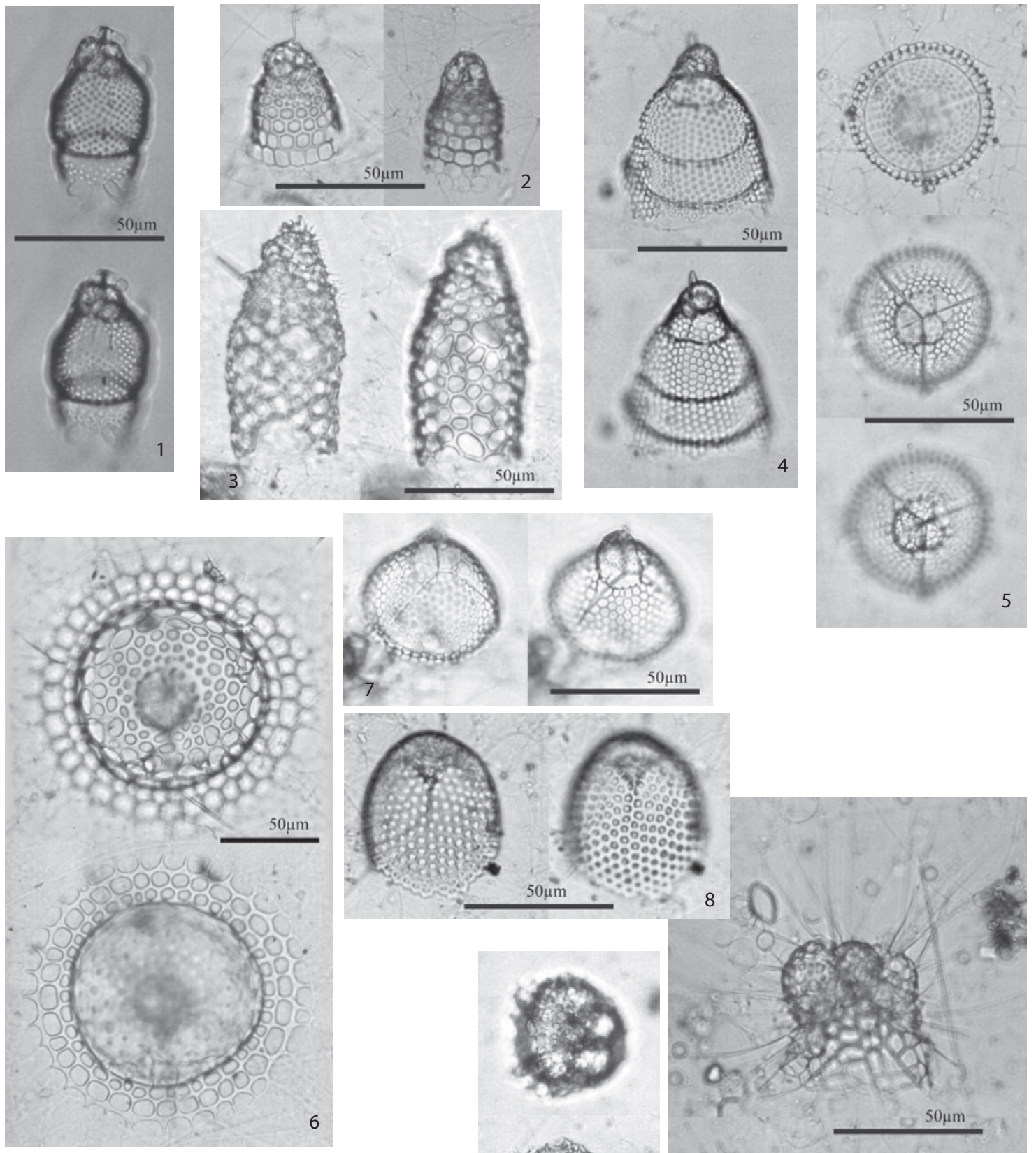

4
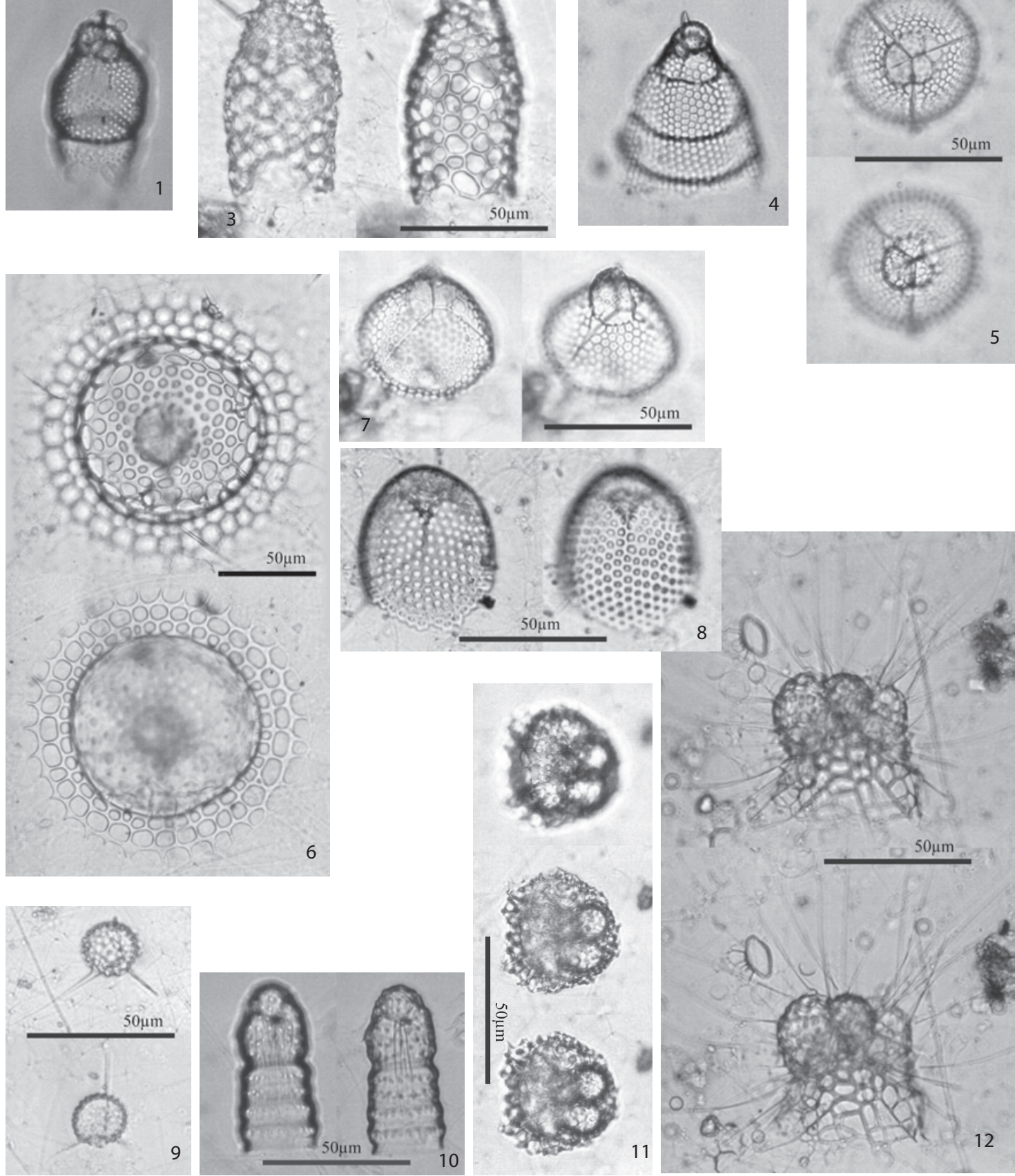

Explanation of Plate 6. figs 1-12. Nassellaria: 1, Artobotrys boreale Cleve, St. R5 slide 7; 2, Artostrobus joergenseni Petrushevskaya, left St. 8b slide 7, right PMO 223.395/1; 3, Artostrobus tabulatus (Ehrenberg), PMO 223.396/1; 4, Eucyrtidium acuminatum (Ehrenberg), St. R5 slide V; 5, Eucyrtidium anomalum (Haeckel), PMO 223.393/1; 6, Corocalyptra craspedota (Jørgensen), PMO 223.396/slide not recorded; 7, Eucyrtidium anomalum (Haeckel), PMO 223.393/2; 8, Carpocanium obliqua (Haeckel), PMO 223.393/3; 9, Lipmanella? sp. juv., top PMO 223.393/2, bottom PMO 223.393/1; 10, Siphocampe lineata (Ehrenberg) clevei Petrushevskaya, St. Ice 19 slide VII; 11, Botryocyrtis scutum (Harting), PMO 223.393/2; 12, Amphimelissa setosa (Cleve), St. Ice 19 slide VII. 

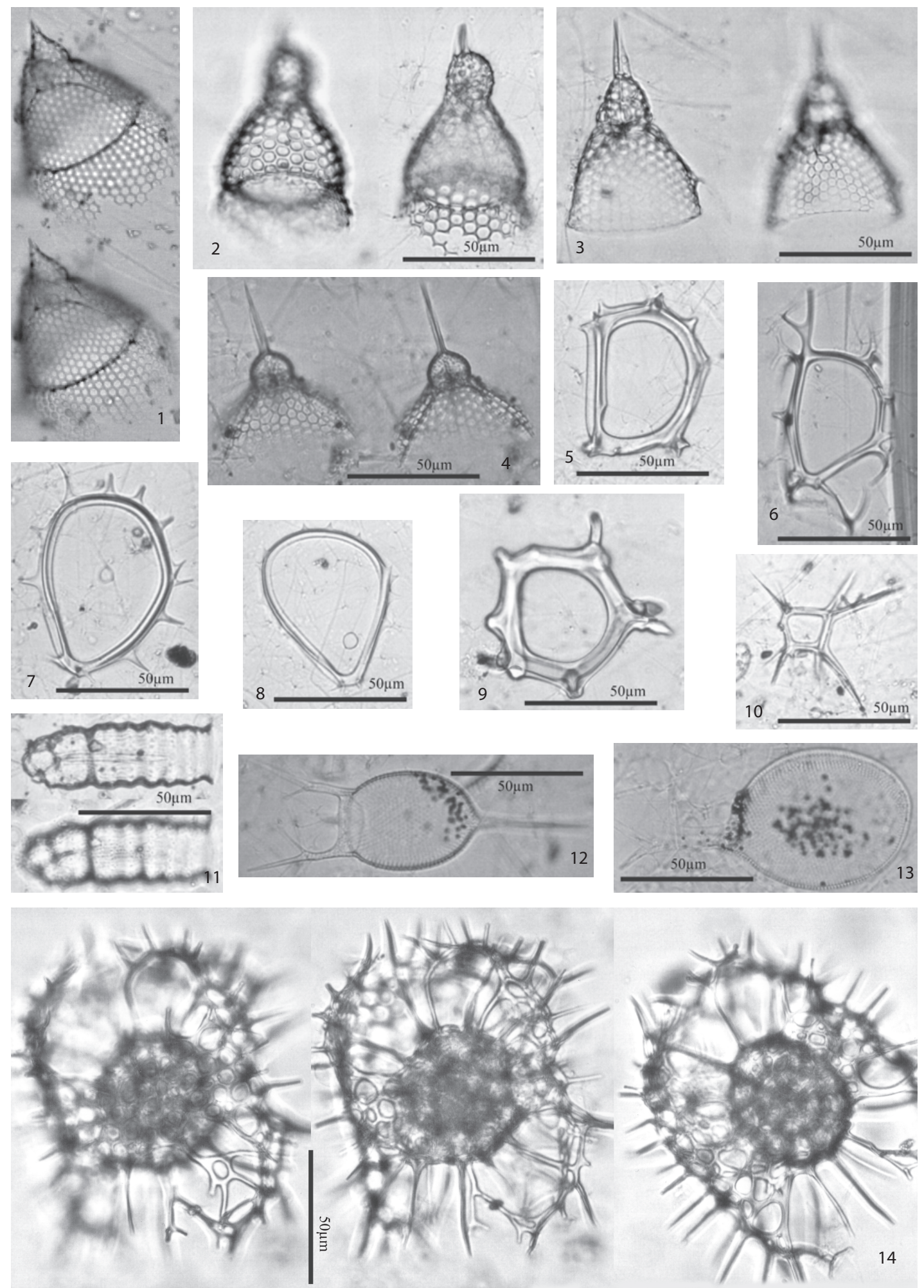

Explanation of Plate 7. figs 1-11. Nassellaria: 1, Pterocorys macroceras (Popofsky), St. R5 slide not recorded; 2, Theocorythium trachelium (Ehrenberg) dianae Nigrini, PMO 223.393/1; 3, Pterocorys zancleus (Müller), St. R5 slide V; 4, Pterocanium praetextum praetextum (Ehrenberg), PMO 223.393/1; 5, Zygocircus piscicaudatus Popofsky, PMO 223.394/2; 6, Nephrodictyum renilla Haeckel, St. R5 slide V; 7, Zygocircus productus Hertwig, PMO 223.393/1; 8, Zygocircus capulosus Popofsky, PMO 223.393/3; 9, Lithocircus annularis Müller, PMO 223.393/2; 10, Zygocircus rhombus (Haeckel) sensu Goll (1979, Pl. 16, figs 1-11), PMO 223.399/2; 11, Siphocampe lineata Ehrenebrg clevei Petrushevskaya, PMO 223.397/1. figs 12, 13. Phaeodaria: 12, Challengeron neptuni Borgert, PMO 223.395/1; 13, Protocystis tridens Haeckel, PMO 223.399/2. fig. 14. A spumellarian: Tetrapylonium clevei Jørgensen, PMO 223.399/4. 
R7b, but with $22 / 6$ at Station Ice19 and 31/13 at Station Ice22 (Table 2). There is clearly a decrease in the ratio of tropical species as we go both north and east, but a more uniform distribution seems to occur eastwards along the continental shelf/upper slope compared to the more northern stations. Only Station R5 is located in open water free of sea ice; all other stations are within the drifting ice. The tropical species outnumber the arctic species at only the two westernmost and southernmost stations (Station R5 and Station 6b), while at the easternmost and northernmost stations the arctic species outnumber the tropical species, both the number of species and the number of specimens. From St. R5 we counted 341 specimens; of these 341 specimens $278(85.5 \%)$ belong to the warm-water assemblage, while only $63(18.5 \%)$ belong to the local cold-water fauna. The value in the Table is calculated as the percentage of taxa, not specimens - hence the difference.

\section{Advected polycystine radiolarian fauna}

Of the 50 warm-water taxa identified to species (number of taxonomically unidentified taxa in parentheses), 7 (1) are Collodaria, 16 (1) are Spumellaria, and 27 (2) are Nassellaria. Among the warm-water taxa we will discuss the occurrence of two species, namely the two spumellarian species Didymocyrtis tetrathalamus (P1. 3, figs 5-7) and Dictyocoryne truncatum (P1. 3, fig. 1). Both species bear algal symbionts (Anderson et al., 1990; Matsuoka, 1992; Matsuoka \& Anderson, 1992). Moreover, laboratory studies indicate that Didymocyrtis tetrathalamus, though commonly found in low latitudes, can survive at temperatures as low as $10^{\circ} \mathrm{C}$, indicating that this species may have potential for adapting to colderwater regimes at higher latitudes (e.g. Anderson et al., 1990). Both species are also co-associated in abundance based on a factor analysis at a low-latitude sampling site (Anderson et al., 1990). These two species in our plankton samples from the Arctic Ocean are dominated by juvenile ontogenetic skeletal forms representing juvenile stages, further suggesting that these two species may be reproducing at our sampling site. The presence of a rather high number of juvenile individuals, belonging to these two species, indicates that these two species most likely temporarily have best adapted to the harsh conditions at these high latitudes. Although it is not possible to determine how many of the cleaned skeletons isolated from the plankton samples represent living forms, we suspect that most of the recovered radiolarian taxa represent living individuals. We conclude this based on the presence of both juvenile and adult stages of the Radiolaria. Moreover, the very long distances that any dead skeletal remains would have to be carried from the tropics to the high latitude locales would most certainly have led to considerable loss due to sinking of the tests and their dissolution in the silicate-undersaturated waters.

Based on our many years of work, we are of the opinion that a reasonable total number of tropical/subtropical species is in the range of 450 to 500 . Given this estimate, it is evident from the limited number of species in our samples that most of the tropicalsubtropical fauna do not survive during advection from the tropical-subtropical region to the arctic. The longevity of radiolarian individuals is approximated to be about one month (Anderson, 1983) based on observations of survival in laboratory culture or estimations from rates of collection in sediment traps, but can be quite variable, e.g. 16-42 days (Takahashi, 1983). Matsuoka \& Anderson (1992) discussed the temperature and salinity tolerance of Dictyocoryne truncatum. Its longevity varied quite considerably from 1-2 days to 5-37 days in cultures of $28^{\circ} \mathrm{C}$ and 35.0 psu. Temperatures below $21^{\circ} \mathrm{C}$ and above $32^{\circ} \mathrm{C}$ suppressed test growth. In the culture experiments $D$. truncatum had a much greater tolerance for survival than for growth. At temperatures as low as $15^{\circ} \mathrm{C}$ the longevity was comparable to that at $28^{\circ} \mathrm{C}$. In the tropics this species may also have a survival advantage during intrusions of colder deeper-water masses (Matsuoka \& Anderson, 1992). In our material, D. truncatum is the only Spongodiscidae that is frequently found, probably a result of its ability to adapt to colder water.

Based on a longevity of about 30 days (Anderson, 1983; Takahashi, 1983) and that the advection time from the Florida Strait to the Fram Strait is about 5-7 years (Dr Helge Drange, personal communication, May 2011), it takes the warm-water assemblage between 60 and 84 generations to reach the Fram Strait area, and a few more generations to reach our sampling area northeast of Svalbard. It is, therefore, possible that many of the tropical-subtropical polycystines have a much higher tolerance to changes in both temperature and salinity in field conditions than previously thought.

\section{Arctic Ocean water masses}

A hydrographic profile of the Arctic Ocean indicates a threelayered water column. A fourth layer of inflow water from the Pacific is present only in the Amerasian Basin (Aagaard et al., 1991; Rudels et al., 1994). At the surface there is a layer of floating ice resting on top of the variable and heterogeneous Arctic surface water $(0-200 \mathrm{~m})$, a layer of water with a temperature that can vary up to $3.5-4^{\circ} \mathrm{C}$ and salinity between 28 and 34 psu. This water is strongly influenced by the large Eurasian and American rivers draining into the Arctic Ocean. The second layer is the warm and salty North Atlantic water (200-900 m), originating from the tropical areas as the Gulf Stream, crossing the North Atlantic as the North Atlantic Current, and flowing into the Arctic Ocean through the Fram Strait as the Norwegian Current with a temperature of $1-3^{\circ} \mathrm{C}$ and a salinity of $34.5-35$ psu. This is also supported by our temperature and salinity data. Finally, the third layer, in the deep parts of the Arctic Ocean is the cold (below $0^{\circ} \mathrm{C}$ ) and salty (34.5-35 psu) water. No trace of the Pacific water, entering through the Bering Strait, is found off northern Spitsbergen (Hülsemann, 1963; Tibbs, 1967; Aagaard et al., 1991; Rudels et al., 1994).

The Norwegian Institute of Marine Research (personal communication to KRB) reported on an unusual oceanographic situation during March 2009 in the water masses west of Svalbard (Fig. 3). They documented an exceptionally high temperature, $7.5^{\circ} \mathrm{C}$, in the core of the Atlantic water, which was $4^{\circ} \mathrm{C}$ above average. One year later, in March 2010, the temperature was reported to be $4.5^{\circ} \mathrm{C}$ and, during August 2010, when our plankton material was collected, the temperature in the core of the Atlantic water at St. Ice 22 was down to the normal $3.5^{\circ} \mathrm{C}$, while it is significantly colder at the shallower stations. An anomaly was observed in the chlorophyll- $a$ measurements in the upper water layer at weather ship station $\mathrm{M}\left(66^{\circ} \mathrm{N}, 2^{\circ} \mathrm{E}\right.$, in the Norwegian Sea). In the time series for the period 1991-2008, an average chlorophyll- $a$ of $2 \mathrm{mg} \mathrm{m}^{-3}$ was obtained at about week 20 (centred around 17 May), while in 2009 the chlorophyll- $a$ measured $4 \mathrm{mg} \mathrm{m} \mathrm{m}^{-3}$, nearly twice the average value. Furthermore, this abnormal peak occurred during the beginning of May, about two weeks earlier than for the average of the time series (Fig. 3 from 
Havforskningsrapporten 21). In the Svinøy $\left(63^{\circ} \mathrm{N}, 2^{\circ} \mathrm{E}\right)$ hydrographic profile, during the first week of May 2009, between 300 and $350 \mathrm{~km}$ off the coast, there is a cell at $20 \mathrm{~m}$ depth with chlorophyll- $a$ values exceeding $5 \mathrm{mg} \mathrm{m}^{-3}$. In the same profile, during the beginning of May, salinities of $35.2 \mathrm{psu}$ and temperatures between $7^{\circ} \mathrm{C}$ and $8^{\circ} \mathrm{C}$ were recorded in the upper $200 \mathrm{~m}$. In June the temperature at about $50 \mathrm{~m}$ had increased to $9^{\circ} \mathrm{C}$, but the salinity maintained at the same value, $35.2 \mathrm{psu}$. It is obvious that during May 2009 something very unusual took place. As the warm-water pulse was detected both in the Fram Strait and in the Svinøy profile at the same time, this indicates that the pulse of warm water must have existed for as long as it took the water to propagate from the Svinøy profile to the Fram Strait, in other words, a strong pulse of increased transport of warm water of Atlantic origin took place.

This warm water, accompanied by 50 identified tropical-subtropical polycystine radiolarian species ( +4 unidentified warmwater taxa), is clear support for the tropical-subtropical origin of this water. Surprisingly, no one who studied the polycystine radiolarians in the Norwegian Sea has seen any, except one species (Euchitonia elegans), of the reported warm fauna elements in the Recent surface sediments in the Norwegian Sea. Moreover, none of these faunal elements was found in the sediment traps positioned in the northern part of the Norwegian Sea and Greenland Sea (Schröder-Ritzrau et al., 2001). These samples were collected from four sediment traps, one GS2 (Greenland Sea), two OG traps (OG3 and OG 4/5, Jan Mayen Current) and one NB (Norwegian Sea). Based on the number of species recovered from the three moorings, the number is c. 30 (in GS), c. 40 (in OG) and c. 50 (in NB) (Schröder-Ritzrau et al., 2001, fig. 2), showing that NB is in rather warm water (their fig. 1), with the Norwegian Current spinning off on each side of the NB mooring, but the mooring is not in the warm-water core. In Bjørklund et al. (1998) it was reported that only sporadic individuals of four warm-water species were observed in the surface sediments of the southern part of the Norwegian Sea (Euchitonia elegans, Spongocore puella, Theocorythium trachelium and Lamprocyclas maritalis), but only one of these (Euchitonia elegans) was observed in our material north of Spitsbergen, as stated above; however, they also recovered different forms of Collodaria, but these were not identified to species. It is, therefore, evident that the Norwegian Current is not a steady carrier of warm-water elements originating from more southern latitudes. As outlined earlier, warm Atlantic water has entered the North Atlantic and Nordic seas in at least two major pulses, in the period 1920 to the middle of the $1950 \mathrm{~s}$, and from about 1990 to present.

Good support for these events was found in the fishery reports. The cod fisheries west of Greenland experienced a significant increase due to the warming of the water masses that took place in the early 1920 s, with a maximum catch of cod in 1927 (Jensen, 1939). Furthermore, it is documented that conifers in Finnmark must have three successive years of warmer climate to produce seeds. This happened in 1918 when the pines flowered, they set good cones in 1919, and finally made good seed in 1920 (Krogness, 1920). A similar exotic radiolarian component was reported by Knipovitsch - who, several times in May 1921, observed the colonial collodarian Collozoum in the waters north of Kola Fjord in Russia (from Jensen, 1939, p. 46). Never before had this type of radiolarian been reported that far east of
Finnmark (northeastern Norway). In our new plankton samples, we have identified eight species of colonial radiolarians, a group that has its highest diversity in the tropical regions. In addition, one of us (SBK) observed several specimens of Euchitonia elegans in the Kara Sea (1985, unpublished data, at that time this finding was interpreted as contamination). Finally, Petrushevskaya (personal communication to KRB, 1972) reported she had seen one specimen of Didymocyrtis tetrathalamus west of Spitsbergen in a sediment surface sample. These are the only observations of tropical-subtropical radiolarians observed at high northeast Atlantic latitudes of which we are aware.

\section{Water masses and fauna provinces}

Such an exotic tropical-subtropical fauna as present in the plankton samples that we report here has never been encountered over the last three decades of studies on Arctic radiolarians (Kruglikova, 1982; 1989; Bjørklund et al., 1998; Bjørklund \& Kruglikova, 2003; Cortese et al., 2003; Kruglikova et al., 2009). The main results of our previous studies indicated that the species composition of Radiolaria in the Arctic Ocean was largely identical to that of other cold-water regions of the World Ocean. The quantitative species - and higher-rank taxa - ratios were, however, specific to, and typical of, the Arctic Ocean; differing substantially from all other cold-water regions.

Furthermore, the Arctic Ocean radiolarian association is quite different from the neighbouring Norwegian Sea and the Bering Sea in the Pacific region. Additionally, the Arctic Ocean has its own set of endemic species of a rather recent age, indicating that there is an active and ongoing speciation, as exemplified in the family Actinommidae (Kruglikova et al., 2009). The Arctic region is characterized by a rather low number of species in the radiolarian assemblages obtained from bottom sediments. Only 31 species were retrieved from the three deep Central Arctic basins, but about 60 were obtained when the cold and shallow marginal seas were included. Typically, only a couple of species are dominant in this realm. At lower (tropical) latitudes the species number increases to between 450 and 500, or probably more, and there are no predominant species.

In the following, we will discuss how the tropical polycystine faunal elements are intruding into the colder northern Arctic waters. As stated earlier, Cleve (1901) pointed out that different water masses are characterized by their water properties, such as temperature and salinity, but equally well by their floral and faunal assemblages. Based partially on this axiom, we conclude that tropical-subtropical fauna elements, inhabiting warm Atlantic water, could reach the Arctic Ocean proper, only if they are carried in the path of the Gulf Stream and the North Atlantic Current. It has been shown that there is a decadal predictability of North Atlantic sea surface temperature and climate, as reported by Sutton \& Allen (1997), who documented a temperature anomaly that took nine years to propagate from the Strait of Florida to the Faeroe Islands. Similarly, Álvarez-García et al. (2008) also reported, based on updated data and models, that the core of the warm Atlantic water would need about nine years to reach the Faeroe Islands from the Strait of Florida. However, the rate of transfer of the temperature anomaly from south to north is slower than the rate of advection (Kettle \& Haines, 2006; Bonhommeau et al., 2010). This implies that water mass tracers, such as in our case the polycystine radiolarian plankton, will need considerably 
less time. Kettle \& Haines (2006) reported that, based on substantial migratory research, the fastest transatlantic migration of Anguilla anguilla larvae in their models was two years - not one year or less, as proposed by Lecomte-Finiger (1992). Bonhommeau et al. (2010) came to roughly the same conclusion that the Atlantic eel needed more than two years to cross the Atlantic Ocean. Dr Helge Drange (personal communication, May 2011) suggested it was generally agreed that a rough estimate for plankton to drift from the Sargasso Sea to the Faeroe Islands would take a little longer, about three years, and somewhat longer from the Strait of Florida, about three to four years. Based on salt, temperature and radioactive tracers, the travel time of the water from the Faeroe Islands to the Fram Strait is on the order of two to three years. Consequently, we can suggest a total advection time for the tropical polycystine radiolarians to be in the range of five to seven years (Florida-Faeroe Island, 3-4 years; Faeroe Island-Fram Strait, 2-3 years; total 5-7 years). Finally, many studies in the North Atlantic aimed to decode the stability or periodicities in the atmospheric and oceanographic circulation patterns, and have concluded that there are predictable changes in sea surface temperature and climate (Sutton \& Allen, 1997; Furevik, 2001; Häkkinen \& Rhines, 2004; Polyakov et al., 2004; 2005; Lohmann et al., 2008; 2009; Hátún et al., 2009; Eldvik et al., 2009).

A summary of some important biogeographical and hydrographic observations is reviewed here in order to provide a framework for our explanation of how warm-water Radiolaria have recently appeared in the Arctic region. Large biogeographical shifts in the northeastern Atlantic Ocean have recently been demonstrated by Hátún et al. (2009). The subpolar gyre is located in the Irminger Sea, Reykjanes Ridge and Iceland Basin region, and is characterized by its large body of cold and low salinity subarctic water. The gyre had an intensive circulation during the early 1990s (Häkkinen \& Rhines, 2004) and experienced a severe decline thereafter (Lohmann et al., 2009). A consequence of the reduced strength and extent of the subarctic gyre was a rapid warming and salinification of the northeastern part of the North Atlantic Ocean. This had a great impact on the distribution of cold water south of Iceland, which now received a replacement of warmer and saltier water from more southern latitudes. Similar events also took place around 1920 to the middle 1950s and as well in the 1990s until present (Fig. 3). During these periods with low intensity in the subpolar gyre, characterized by warm water, many boreal fishes invaded Icelandic and Greenlandic waters (Hátún et al., 2009). This last happened in 1995/1996 and a gradual warming and salinification has taken place in the North Atlantic and Norwegian Sea. The subpolar front is the periphery of the subpolar gyre and is an effective barrier for several copepod taxa (Gaard et al., 2008). The North Atlantic subpolar gyre has a highly variable volume of cold and low salinity water. Consequently we infer that the relatively well-defined water boundaries are effective boundaries for the distribution of the primary producers as well as for the secondary consumers at all levels (protozoans, crustaceans, fish, and mammals), as has been suggested by Hátún et al. (2009). The northeastern Atlantic ecosystem is, therefore, strongly influenced by the structure of the North Atlantic subpolar gyre, which controls the pronounced changes in fauna, not only in the northeastern North Atlantic, but even extends from the English Channel in the south to the Barents
Sea-Fram Strait in the north, as well as off Greenland in the northwest. Such changes have occurred several times, with a significant rise in temperature and corresponding changes in the pelagic and planktonic communities. Thornalley et al. (2009) indicated that the marine climate had probably been regulated by the subarctic gyre in the northeastern North Atlantic throughout the last c. 11700 years, the entire Holocene.

From 1995/1996 there is a fairly well-documented intense warming and increasing salinity in the northern seas (Holliday et al., 2008; Hátún et al., 2009), and it is well accepted that warm Atlantic water definitely reaches the Arctic Ocean in pulses that have a great interannual and multidecadal variability (Polyakov et al., 2005). A time series of calanoid copepods and temperature in the Iceland Basin-Rockall Plateau area from 1960 to 2000, shows a close relation between the two. Copepod and temperature values decreased from 1960 to 1975, increased until early 1980s, but once again decreased until about 1995, and from then on increased until 2005, the end of the time series (Hátún et al., 2009).

Holliday et al. (2008, L03614) stated

the time lag estimates would allow us to make some short term empirical predictions about conditions at the entrance to the Arctic Ocean. The Faroe-Shetland Channel salinity began to increase in 1996, reached a peak in 2004, and showed a slight decrease since then (2005-2006). Temperatures peaked in 2003 but remained high in 2005 and 2006. We can therefore predict that Fram Strait temperature may start to decline in 2007 or 2008, while salinity will peak a year later, but both will remain high at least until 2010.

Temperature results, moreover, show that there has been a significant drop in temperatures west and northwest of Svalbard from 2009 to 2010 (Fig. 3). Their final statement is that both 'temperature and salinity have decreased slightly at the more southern locations since 2003 or 2004, but the interannual variability overlaying the multi-decadal scale pattern means it will be several years before we can conclude whether a new maximum has passed' (Holliday et al., 2008, L03614).

\section{Earlier warm-water pulses in the Arctic Ocean}

We have no direct radiolarian data that can answer the question whether earlier warm-water pulses occurred in the Arctic Ocean, because opal microfossil remains are poorly preserved in the Arctic Ocean sediment cores due to dissolution. This is evident in our new plankton material where Amphimelissa setosa is an abundant species at all stations, but is only represented in the Nansen Basin surface sediments with a few individuals. The same is the case with an undescribed Arachnocorys sp. (Pl. 5, fig. 8), probably endemic to the Arctic Ocean and one of the commonest species in the plankton, but so far not observed in the sediment. Therefore, to further support that the occurrence of these warm tropical radiolarians is a result of warm-water pulses in the Arctic, we cite data on planktonic foraminifers, among other evidence.

Evidence of thermophilic planktonic foraminifera has been reported in the late Holocene Laptev Sea (Core 7, 74 $53^{\prime} \mathrm{N}$; $129^{\circ} 59^{\prime}$ E) (Matul et al., 2007) with approximately $96 \%$ of the assemblage consisting of thermophilic species at two short time intervals at about 6100 and about 6200 years BP. Bauch (1999) 
also reported on tropical-subtropical planktonic thermophilic foraminifer associations, and identified three intervals in core IK9373$10\left(75^{\circ} 20^{\prime} 8^{\prime \prime} \mathrm{N} ; 135^{\circ} 12^{\prime} 3^{\prime \prime} \mathrm{E}\right)$, dated to about 874-925, 1640 and 1790 years BP. The occurrence of such warm-water assemblages can only be explained as a result of reworking of older sediments, or as episodes with strong inflow of warm Atlantic water. Hitherto, no one has reported on locations with sediments containing a tropical-subtropical fauna. Therefore, we infer the tropicalsubtropical planktonic thermophilic foraminifer associations, as for the tropical-subtropical radiolarian fauna, to be related to large changes in the pulses of warm Atlantic water. We note, however, that Volkmann (2000) reported that the Recent planktonic foraminifera assemblage from the Laptev Sea consists of: Neogloboquadrina pachyderma (sinistral) $>70 \%$, Turborotalia quinqueloba and Neogloboquadrina pachyderma (dextral), an assemblage that is very different from the associations assumed to represent episodes with a high inflow of warm Atlantic water. However, Volkmann (2000) also reported that in the collected water samples there were also about $0.5-2 \%$ of empty tests of thermophilic planktonic foraminifera. Their origin is unknown, but it is also likely here that these empty warm-water foraminifer tests belonged to the incoming warm Atlantic water and represent dead individuals. As mentioned above, radiolarian skeletons present a very different scenario, the silicate is more readily dissolved; for example only a small percentage of dead skeletons arrive intact when settling into ocean sediments (e.g. Lizitsin, 1972). Thus, we conclude that the presence of juvenile and adult stages in our samples of Radiolaria most likely represent individuals that were alive in the water column, especially given the density of the silicate tests that would have very likely settled out of the water column soon after death, if it occurred. Their presence, undoubtedly, is evidence of an incursion of warm water from the Atlantic and is not a result of global warming.

\section{Implications for ecology and population}

Our plankton sample data clearly show that, at least within recent time, a major influx of lower latitude Radiolaria has occurred among the otherwise low diversity assemblages typically found in the Arctic Ocean. This intrusion, probably due to the break-up of the subpolar gyre that normally serves as a barrier, undoubtedly changed the hydrographic and ecological dynamics of the Arctic Ocean environment. Increased biological diversity is likely to have some positive ecological effects, including possibly greater stability of the communities against short-term variations in environmental variables, such as salinity, temperature and available nutrients in the surface water. Those species that are most adapted to colder water are more likely to be resistant to rapid decreases in temperature, while warmer-water species that have become adapted to more moderate temperature regimes may be resistant to increasing temperatures associated with major climatic shifts such as global warming. However, increased diversity due to intrusion of alien species may also lead to intraspecific competition, especially if their presence increases biological densities, and more so if there is no niche differentiation between the indigenous species and the intrusive ones. For example, if the intrusive species utilize different prey than the indigenous species, leading to trophic differentiation, there may be less competitive pressures between the two groups. On the other hand, if there is considerable overlap in prey preferences, some competitive exclusion may take place. We have only meagre evidence of the prey preferences of various microplankton species, especially the Radiolaria. However, some evidence indicates that smaller species, abundant in the picoplankton of the Arctic Ocean (Lovejoy et al., 2006), may be largely predators on bacteria and algal microplankton species, while larger species can consume both phytoplankton and small zooplankton prey (e.g. Anderson, 1983; Anderson et al., 1990). If this is the case, some of the smaller typically Arctic species, may prey on the microplankton, while some larger lower latitude species may consume larger plankton prey. Some lower latitude species also harbour abundant algal and/or cyanobacterial symbionts that provide at least partial nutrition (e.g. Anderson, 1983; Anderson et al., 1989), and it is not fully determined how this contribution may affect community trophodynamics during intermingling of formerly geographically isolated communities of picoplankton and Radiolaria. The algal symbionts in some species have been shown to contribute organic compounds to the host that may help to sustain its nutrition (Anderson, 1983). However, it is not known how these symbionts would adapt to conditions of darkness, such as those that occur for substantial time during winter at high latitudes, nor how much loss of photosynthetic-derived nourishment during winter would affect the radiolarian host.

A major issue concerns possible differences in categories of prey in the Arctic Ocean compared to lower latitudes. If the intrusive lower latitude species are fairly cosmopolitan in their predatory preferences, they may be able to adjust to the new trophic regimes with minor effects on growth and reproduction. However, it remains to be determined how effectively these expatriated lower latitude species adjust to, and exploit, higher latitude environments. Further plankton sampling evidence, and longer-term analyses of core top samples, may provide some evidence of the relative success, if at all, of these intrusive species as well as the response of the indigenous radiolarian taxa. As Holliday et al. (2008) pointed out, it could be predicted that both salinity and temperature would remain high at least until 2010, but that it would take several additional years before it could be concluded whether a new temperature/salinity maximum has passed. If the recent warm pulse reported on herein is soon expected to be over, then the inflow of exotic radiolarians will be reduced, and it is a question of how this introduced fauna will behave. Will it persist or will it gradually vanish?

The intrusion of geographically alien species also changes the gene pool in the local populations and potentially could alter population composition and dynamics if there is interbreeding among species. Our knowledge of population dynamics, and especially the details of sexual reproduction in Radiolaria, is very limited. Current evidence clearly documents asexual reproduction in some species (especially colonial ones). Moreover, the formation of flagellated swarmers at maturity, as observed in laboratory cultures, suggests that these are gametes. However, presently, there is no evidence of syngamy and second-generation growth. The application of molecular genetic analyses (e.g. de Vargas et al., 1999; Darling et al., 2000; both on planktonic foraminifera), however, may provide indirect evidence of mingling of gene pools, especially if sufficient properly preserved plankton material can be obtained and analysed in longer, time-series studies following intrusion of non-endemic species of Radiolaria. However, until we know more clearly to what extent hybridization and production of viable offspring can occur in Radiolaria, we will need to rely 
particularly on indirect indicators, such as molecular genetics. Application of molecular genetic screening (e.g. Lovejoy et al., 2006) can provide a much more sensitive means of identifying the richness and diversity of radiolarian species, especially documenting the occurrence of cryptic species that otherwise may go unnoticed due to their very low frequency of occurrence. Such low-density species, while not necessarily a major ecological factor at a given point in time, may be potentially adaptive to changing environments and become more dominant if more favourable environmental conditions occur. Also, cryptic species may be a source of potential genetic diversity, providing a richer gene pool to seed diversification through interbreeding and species divergence as environmental selection pressures change. More recently, Lovejoy \& Potvin (2011) reported that c. $40 \%$ of the retrieved molecular genetic clones from samples in the Beaufort Sea and Arctic Ocean were Radiolaria, further suggesting that Radiolaria may be more abundant proportionately than previously thought, and further strengthening the case for the merits of additional geographically widespread molecular genetic sampling in high latitude oceans.

In addition to the ecological and genetic aspects of major intrusions of non-indigenous species, there is the possible effect of selection pressures in the new environment leading to increased rates of speciation, as has been documented in experimental and natural field-based studies for a variety of organisms (e.g. Orr \& Smith, 1998). Moreover, invasion of new territories may also result in certain ecological factors that essentially isolate the invading species, perhaps due to different domains they inhabit within the new environment, or due to restricted periods of time when sexual reproduction occurs in the new habitat. Thus, invasion of new species within a habitat can lead to either more rapid speciation in some cases, or de facto increased reproductive isolation, thus reducing the potential for mixing of gene pools that otherwise might lead to more rapid genetic differentiation among species (e.g. Orr \& Smith, 1998).

The recent intermingling of low latitude radiolarian species with the indigenous cold-water species in the Arctic Ocean provides a 'natural laboratory' to further explore the ecological and evolutionary implications of this infrequent event. Clearly, the Arctic Ocean is a dynamic and changing ecosystem that deserves much more intensive research study, especially among biomineralizing microplankton that are among some of the most productive sources of proxy evidence for ancient and modern processes of climate and environmental change.

\section{SUMMARY}

Beginning with work early in the twentieth century (e.g. Cleve, 1901 ; 1903), it was assumed that certain marker plankton species could be used to trace changes in water masses in different specific geographical locales, a topic we have explored particularly in this research. As documented more fully in this report, radiolarians with their high species number and characteristic forms can serve as a good monitoring tool for pulses of warm Atlantic water entering the Norwegian Sea and finally into the Arctic Ocean proper. Surprisingly, a suite of obviously tropical-subtropical species was able to invade and apparently establish reproductive populations in the rather hostile and harsh, cold-water environment of the Arctic Ocean - quite different from their normal environments. Among radiolarians in general, this may be a good example of ecotypic plasticity. Water temperature is clearly a major environmental variable, and the radiolarians as a group should be followed up during subsequent years to monitor, among other factors, the variation in northward distribution, possible penetration into the polar basin, and with proper sampling and preservation of specimens, application of modern molecular genetic techniques to more fully explore possible changes in abundances and evidence of genetic variability.

Based on earlier observations and our new data we conclude that in the prior century there were several pulses of warm water into the Arctic Ocean caused by natural climatic changes, such as intensity changes in the North Atlantic subpolar gyre. Thus, it is unlikely that this intrusion is specifically related to recent global warming events and climate change. Similar warm-water pulses, therefore, will very likely come and go in the centuries to come. Among other variables affecting high latitude hydrographic features, the North Atlantic Oscillation (NAO) may account for decadal/subdecadal surface current and temperature variability, and may contribute partially to the forcing functions driving warmwater incursions. We propose polycystine radiolarians in the plankton can be a valuable marker to identify changes in the northward flow of the warm North Atlantic water.

\section{CONCLUSIONS}

1. Tropical polycystine radiolarians (in all orders of polycystines) were found at seven stations in plankton samples in the Arctic Ocean proper, more precisely on the southern flank of the Nansen Basin.

2. A significant warm-water pulse was detected in 2009 by temperature $\left(7.5^{\circ} \mathrm{C}\right)$, salinity $(35.2 \mathrm{psu})$ and chlorophyll- $a$ $\left(5 \mathrm{mg} \mathrm{m}^{-3}\right)$ measurements.

3. Stations R5 and $6 \mathrm{~b}$ both document a dominance of tropical polycystine species 13/85 (arctic/tropical) and 9/20, respectively; spyrids and collodarians were present with many morphological forms.

4. Didymocyrtis tetrathalamus and Dictyocoryne truncatum, both observed along with a majority of juvenile forms, indicate that these two species most likely have adapted best to the new environments.

5. Based on multiple lines of evidence, including the time for reproduction, it has likely taken these two species 5-7 years to move from the Florida Strait to the Fram Strait, possibly 60-84 generations between the two straits, sufficient time to permit adaptation to the new northern conditions.

6. The present warm-water pulse is predicted to stop at the end of 2010; if so, will the introduced warm-water fauna collapse, or will it share genes with the local polycystine radiolarians and possibly persist?

\section{ACKNOWLEDGEMENTS}

We are grateful for the support of the Centre for Ice, Climate and Ecosystems (ICE) at the Norwegian Polar Institute, which has provided biological data samples, and especially Dr Arild Sundfjord who provided hydrography data, a map figure, and who has been a discussion partner in the development of the manuscript. Similarly we thank Dr Randi Ingvaldsen, Institute of Marine Research, Bergen for providing, and allowing us to use, a high resolution copy of Figure 3, and Dr Helge Drange, Bjerknes 
Centre for Climate Research, University of Bergen for valuable discussions. Drs G. Cortese and N. Suzuki carefully reviewed this manuscript and provided valuable suggestions. Dr Cathy Stickley has been particularly helpful in providing editorial guidance. Finally, we express sincere appreciation for the generous encouragement and hospitality provided by Turid Axelsen during Svetlana B. Kruglikova's research visits to Norway. This is Lamont-Doherty Earth Observatory Contribution number 7520.

\section{Manuscript received 31 October 2011 \\ Manuscript accepted 20 January 2012}

Scientific Editing by Catherine Stickley.

\section{REFERENCES}

Aagaard, K., Fahrbach, E., Meincke, J. \& Swift, J.H. 1991. Saline outflow from the Arctic Ocean: Its contribution to the deep waters of the Greenland, Norwegian, and Iceland Seas. Journal of Geophysical Research, 96: 20433-20441.

Álvarez-García, F., Latif, M. \& Biastoch, A. 2008. On multidecadal and quasi-decadal North Atlantic variability. Journal of Climate, 21: 3433-3452.

Anderson, O.R. 1983. Radiolaria. Springer, New York, 355pp.

Anderson, O.R., Bennett, P., Angel, D. \& Bryan, M. 1989. Experimental and observational studies of radiolarian physiological ecology: 2. Trophic activity and symbiont productivity of Spongaster tetras tetras with comparative data on predatory activity of some Nassellarida. Marine Micropaleontology, 14: 267-273.

Anderson, O.R., Bryan, M. \& Bennett, P. 1990. Experimental and observational studies of radiolarian physiological ecology: 4. Factors determining the distribution and survival of Didymocyrtis tetrathalamus tetrathalamus with implications for paleoecology. Marine Micropaleontology, 16: 155-167.

Bauch, H.A. 1999. Planktonic foraminifera in Holocene sediments from the Laptev Sea and the Central Arctic Ocean: Species distribution and paleobiogeographical implications. In Kassens, H., Bauch, H. A., Dmitrenko, I. A., et al. (Eds), Land-Ocean Systems in the Siberian Arctic: Dynamics and History. Springer, Berlin, 601-613.

Bernstein, T. 1934. Zooplankton des Nordischen teiles des Karischen Meeres. Transactions of the Arctic and Antarctic Research Institute, IX: 3-58 [In Russian with German summary].

Bjørklund, K.R., Cortese, G., Swanberg, N. \& Schrader, H.J. 1998. Radiolarian faunal provinces in surface sediments of the Greenland, Iceland and Norwegian (GIN) Seas. Marine Micropaleontology, 35: $105-140$.

Bjørklund, K.R. \& Kruglikova, S.B. 2003. Polycystine radiolarians in surface sediments in the Arctic Ocean basins and marginal seas. Marine Micropaleontology, 49: 231-273.

Boltovskoy, D., Kling, S.A., Takahashi, K. \& Bjørklund, K. 2010. World atlas of distribution of recent polycystina (Radiolaria). Palaeontologia Electronica, 13: 18A.

Bonhommeau, S., Castonguay, M., Rivot, E., Sabatié, R. \& Le Pape, O. 2010. The duration of migration of Atlantic Anguilla larvae. Fish and Fisheries, 11: 289-306.

Cleve, P.T. 1900. Plankton collected by the Swedish Expedition to Spitzbergen in 1898. Kongliga Svenska Vetenskaps-Akademiens Handlingar, 32: 1-51.

Cleve, P.T. 1901. The seasonal distribution of Atlantic plankton organisms. Göteborgs Kungliga vetenskaps-och vitterhetssamhalles handlingar, 4: 1-369.

Cleve, P.T. 1903. Plankton researches in 1901 and 1902. Kongliga Svenska Vetenskapsakademiens Handlingar, 36: 1-53.

Cortese, G., Bjørklund, K.R. \& Dolven, J.K. 2003. Polycystine radiolarians in the Greenland-Iceland-Norwegian (GIN) Seas: Species and assemblage distribution. Sarsia, 88: 65-88.
Darling, K.F., Wade, C.M., Stewart, I.A., Kroon, D., Dingle, R. \& Brown, A.J.L. 2000. Molecular evidence for genetic mixing of Arctic and Antarctic subpolar populations of planktonic foraminifers. Nature, 405: $43-47$.

de Vargas, C., Norris, R., Zaninetti, L., Gibb, S.W. \& Pawlowski, J. 1999. Molecular evidence of cryptic speciation in planktonic foraminfers and their relation to oceanic provinces. Proceedings of the National Academy of Science USA, 96: 2864-2868.

Dolven, J.K., Cortese, G. \& Bjørklund, K.R. 2002. A high-resolution radiolarian derived paleotemperature record for the Late PleistoceneHolocene in the Norwegian Sea. Paleooceanography, 17: 1072.

Dumitrica, P. 1988. New families and subfamilies of Pyloniacea (Radiolaria). Revue de Micropaléntologie, 31: 178-195.

Eldvik, T., Nilsen, J.E.Ø., Iovino, D., Olsson, K.A., Sandø, A.B. \& Drange, H. 2009. Observed sources and variability of Nordic seas overflow. Letters. Nature Geoscience, 2: 406-410. DOI: 10.1038/NGEO518.

Ehrenberg, C.G. 1844. Über 2 neue Lager von Gebirgsmassen aus Infusorien als Meeres-Absatz in Nord-Amerika und eine Vergleichung derselben mit den organischen Kreide-Gebilden in Europa und Afrika. Konigliche Preussische Akademie der Wissenschaften zu Berlin, Bericht, Jahre 1844: 57-97.

Ehrenberg, C.G. 1847. Über die mikroskopischen Kieselschaligen Polycystinen als machtige Gebirgsmasse von Barbados. Konigliche Preussische Akademie der Wissenschaften zu Berlin, Bericht, Jahre 1847: 54.

Ehrenberg, C.G. 1854. Mikrogeologie. Verlag L. Voss, Leipzig, 374pp., 40 pls, 88 atlas.

Ehrenberg, C.G. 1860. Über den Tiefgrund des stillen Oceans Inseln aus bis 15600 ' Tiefe nach Lieutenant Brooke. Monatsberichte der Königlich Preussishcen Akademie der Wissenshaften zu Berlin, Abhandlung 1860: 819-833.

Ehrenberg, C.G. 1872. Mikrogeologischen Studien als Zusammenfassung seiner Beiobachtunen des kleinsten Lebens der Meeres-Tiefgrunde aller Zonen und dessen geologischen Einfluss. Monatsberichte der Königlich Preussishcen Akademie der Wissenshaften zu Berlin, Jahrgang 1872: 265-322.

Furevik, T. 2001. Annual and interannual variability of Atlantic Water temperatures in the Norwegian and Barents Seas: 1980-1996. Deep-Sea Research I, 48: 383-404.

Gaard, E., Gislason, A., Falkenhaug, T., Soiland, H., Musaeva, E., Vereshchaka, A. \& Vinogradov, G. 2008. Horizontal and vertical copepod distribution and abundance on the Mid-Atlantic Ridge in June 2004. Deep-Sea Research Part II - Topical Studies in Oceanography, 55: 59-71.

Goll, R.M. 1979. The neogene evolution of Zygocircus, Neosemantis and Callimitra: Their bearing on nasselarian classification. Micropaleontology, 25: 365-396.

Haeckel, E. 1887. Report on the Radiolaria collected by the H.M.S. Challenger during the Years 1873-1876. Report on the Scientific Results of the Voyage of the H.M.S. Challenger, Zoology, 18: 1-1803.

Häkkinen, S. \& Rhines, P.B. 2004. Decline of subpolar North Atlantic circulation during the 1990s. Science, 304: 555-559.

Harting, P. 1863. Bijdrage tot de kennis der mikroskopische fauna en flora van de Banda-Zee. Verhandelingen koninklijk Akademie Wetenschappen, Amsterdam, 10: 1-34.

Hátún, H., Payne, M.R., Beaugrand, G. et al. 2009. Large bio-geographical shifts in the north-eastern Atlantic Ocean: From the subpolar gyre, via plankton, to blue whiting and pilot whales. Progress in Oceanography, 80: $149-162$.

Holliday, N.P., Hughes, S.L., Bacon, S. et al. 2008. Reversal of the 1960 s to 1990 s freshening trend in the northeast North Atlantic and Nordic Seas. Geophysical Research Letters, 35: L03614. DOI: 10.1029/2007GL032675.

Hülsemann, K. 1963. Radiolaria in Plankton from the Arctic Drifting Station T-3, including the description of three new species. Arctic Institute of North America, Technical Paper, 13: 1-52. 
Itaki, T. \& Bjørklund, K.R. 2007. Conjoined radiolarian skeletons (Actinommidae) from the Japan Sea sediments. Micropaleontology, 53: 371-389.

Itaki, T., Ito, M., Narita, H., Ahagon, M. \& Sakai, I. 2003. Depth distribution of radiolarians from the Chukchi and Beaufort Seas, western Arctic. Deep-Sea Research Part I, 50: 1507-1522.

Jensen, A.S. 1939. Concerning a change of climate during recent decades in the Arctic and Subarctic Regions, from Greenland in the west to Eurasia in the east, and contemporary biological and geophysical changes. Det Kongelige Danske Videnskabernes Selskab, Biologiske Meddelelser, XIV: 1-75.

Johnson, D.A. 1974. The dissolution of siliceous microfossils in surface sediments of the eastern tropical Pacific. Deep-Sea Research, 21: 851-864.

Jørgensen, E. 1905. The Protist plankton and the diatom in bottom samples. VII. Radiolaria. In: Nordgaard, O. (Ed.), Hydrographical and Biological Investigations in Norwegian Fiords. Bergens Museum, 114-142 (+11 radiolarian).

Kettle, A.J. \& Haines, K. 2006. How does the European eel (Anguilla anguilla) retain its population structure during its larval migration across the North Atlantic Ocean? Canadian Journal of Fisheries and Aquatic Science, 63: 90-106. DOI: 10.1139/F05-198.

Krogness, O. 1920. Klimavekslinger belyst ved en undersøkelse over skogenes fornyelse i Nord-Norge. Den Polytekniske Forening for Troms og Finmark Fylker, 1: 3-14. (Presentation given at a society meeting 29 October 1920.)

Kruglikova, S.B. 1969. Radiolyarii v poverkhnostnom sloe osadkov severnoi poloviny tikhogo okeana [Radiolarians in the surface layer of the sediments of the northern half of the Pacific Ocean]. In Kort, V.G. (Ed.), Mikroflora i Mikrofauna v Sovremennykh Osadkakh Tikhogo Okean [Microflora and Microfauna in the Recent Sediments of Pacific Ocean]. Nauka, Moscow, 48-72.

Kruglikova, S.B. 1977. Radiolaria. In Jouse, A.P. (Ed.), Atlas of Microorganisms in Bottom Sediments of the Oceans: diatoms, radiolaria, silicoflagellates and coccoliths. Academy of Sciences USSR, Nauka, Moscow, 7, 13-17 (pls 86-145).

Kruglikova, S.B. 1981. Radiolarii v poverkhnostnom sloe osadkov vostochnoi chasti tropicheskoy zoni Tikhogo okeana [Radiolaria in the surface sedimentary layer in the eastern part of the Pacific tropical zone]. Okeanologia, 21(3): 499-506.

Kruglikova, S.B. 1982. Radioljarii iz sovremennykh donnykh otlozhenii Arkticheskogo basseina po materialam SP-15 I SP-22. [Radiolaria in recent bottom deposits of the Arctic Basin based on material from SP-15 and SP-22]. In Lisitsyn, A.P. (Ed.), Geologia morei i okeanov: Tezisy dokladov 5-oi Vesoiuznoi shkoly morskoi geologii [Geology of the seas and oceans. Abstracts of Reports of the 5th All-Union School of Marine Geology]. Three vols. IO AN SSSR, Moscow.

Kruglikova, S.B. 1988. Radiolaria (Polycystina) from the Arctic bottom sediments. Izvestia Academii nauk (Academy of Science), USSR, Seriya Geologia, 1: 92-102.

Kruglikova, S.B. 1989. Arctic Ocean Radiolaria. In Herman, I. (Ed.), The Arctic Seas: Climatology, Oceanography, Geology and Biology. Van Nostrand Reinhold, New York, 461-480.

Kruglikova, S.B. 2009. Data on the distribution of high rank taxa of Polycystina in the bottom sediments and their connection with the environment. In The 12th Meeting of the International Association of Radiolarian Paleontologists. Radiolaria through time, 14-17 September, 2009. Programme and Abstracts. Nanjing, China, 319-320.

Kruglikova, S.B. 2011. Radiolaria-Polycystina from the bottom deposits of the World Ocean as bioindicators of the environment fluctuations. (Author's abstract of doctoral dissertation.) 'Gallea Print', GeologicalMineralogical Sciences, Speciality-oceanology, P.P. Shirshov Institute of Oceanology, Russian Academy of Sciences, Moscow, 38 (MS) [In Russian].
Kruglikova, S.B., Bjørklund, K.R., Hammer, Ø. \& Anderson, O.R. 2009. Endemism and speciation in the polycystine radiolarian genus Actinomma in the Arctic Ocean: Description of two new species Actinomma georgii n. sp. and A. turidae n. sp. Marine Micropaleontology, 72: 26-48.

Lecomte-Finiger, R. 1992. Growth history and age at recruitment of European glass eels (Anguilla anguilla) as revealed by otolith microstructure. Marine Biology, 114: 205-210.

Lizitsin, A.P. 1972. Sedimentation in the World Ocean. Society of Economic Paleontologists and Mineralologists, Special Publication, 17. Georg Banta Company, Inc., Menasha, Wisconsin, 218pp.

Lohmann, K., Drange, H. \& Bentsen, M. 2008. Response of the North Atlantic subpolar gyre to persistent North Atlantic oscillation like forcing. Climate Dynamics, 32: 273-285. DOI. 10.1997/s00382008-0467-6.

Lohmann, K., Drange, H. \& Bentsen, M. 2009. A possible mechanism of the strong weakening of the North Atlantic subpolar gyre in the mid-1990s. Geophysical Research Letters, 36: L15602. DOI: 10.1029/2009GL039166.

Lovejoy, C. \& Potvin, M. 2011. Microbial eukaryotic distribution in a dynamic Beaufort Sea and the Arctic Ocean. Journal of Plankton Research, 33: 431-444.

Lovejoy, C., Massana, R. \& Pedrós-Alio, C. 2006. Diversity and distribution of marine microbial eucaryotes in the Arctic Ocean and adjacent seas. Applied and Environmental Microbiology, 72: 3085-3095. DOI: 10.1128/AEM.72.5.3085-3095.2006.

Matsuoka, A. 1992. Skeletal growth of a spongiose radiolarian Dictyocoryne truncatum in laboratory culture. Marine Micropaleontology, 19: 287-297.

Matsuoka, A. \& Anderson, O.R. 1992. Experimental and observational studies of radiolarian physiological ecology: 5 . Temperature and salinity tolerance of Dictyocoryne truncatum. Marine Micropaleontology, 19: 299-313.

Matul, A.G., Khusid, T.A., Mukhina, V.V., Chekhovskaya, M.P. \& Safarova, S.A. 2007. Recent and Late Holocene environments on the southeastern shelf of the Laptev Sea as inferred from microfossil data. Oceanology, 47: 80-90.

Müller, J. 1858a. Über die Thalassicollen, Polycystinen und Acanthometren des Mittelmeeres. Konigliche Preussische Akademie der Wissenschaften zu Berlin, Abhandlung, 1858: 1-62.

Müller, J. 1858b. Einige neue bei St. Topez am Mittelmeer biobachtete Polycystinen und Acanthometren. Konigliche Preussische Akademie der Wissenschaften zu Berlin, Abhandlung, 1858: 154-155.

Nigrini, C.A. 1967. Radiolaria in pelagic sediments from the Indian and Atlantic Oceans. Bulletin of the Scripps Institution of Oceanography, 11: $1-125$.

Nigrini, C.A. \& Moore, T.C. 1979. A Guide to Modern Radiolaria. Cushman Foundation for Foraminiferal Research, Special Publication, 16. Washington, D.C.

Orr, M.R. \& Smith, T.B. 1998. Ecology and speciation. Trends in Ecology and Evolution, 18: 502-506.

Petrushevskaya, M.G. 1967. Radiolarians of orders Spumellaria and Nassellaria of the Antarctic region. In Andriyashev, A.P. \& Ushakov, P.V. (Eds), Studies of Marine Fauna IV (XII). Biological Reports of the Soviet Antarctic Expedition (1955-1958), 3: 2-186 [In Russian; English edition 1968].

Petrushevskaya, M.G. 1971. Radiolyarii Nassellaria v planktone Mirovogo Okeana. Issledovaniya Fauny Morei, 9. Nauka, Leningrad, 294pp. [In Russian].

Polyakov, I.V., Alekseev, G.V., Timokhov, L.A. et al. 2004. Variability of the intermediate Atlantic Water of the Arctic Ocean over the last 100 years. Journal of Climate, 17: 4485-4497.

Polyakov, I.V., Beszczynska, A., Carmack, A.E. et al. 2005. One more step toward a warmer Arctic. Geophysical Research Letters, 32: L17605. DOI: 10.1029/2005GL023740, 2005. 
Popofsky, A. 1912. Die Sphaerellarien des Warmwassergebietes. Deutsche Südpolar-Expedition 1901-1903, Zoologie II, 13: 73-159.

Popofsky, A. 1913. Die Nassellarien des Warmwassergebietes. Deutsche Südpolar-Expedition (1901-1903), 14: 217-416.

Popofsky, A. 1917. Die Collosphaeriden der Deutschen Sudpolar-Expedition 1901-1903. Mit Nachtrag zu den Spumellarien und Nassellarien. In Drygalski, E. (Ed.), Deutsche Sudpolar-Expedition, 1901-1903, 16 [Zool. vol. 8], part 3, no. 9. Walter de Gruyter, Berlin, Germany, 235-278.

Renz, G.W. 1976. The distribution and ecology of Radiolaria in the Central Pacific: Plankton and surface sediments. Bulletin of the Scripps Institution of Oceanography, 22: 1-267.

Riedel, W.R. 1958. Radiolaria in Antarctic sediments. B.A.N.Z. Antarctic Research Expedition Reports, Series B, 6: 217-255.

Rudels, B., Jones, E.P, Anderson, L.G. \& Kattner, G. 1994. On the intermediate depth waters of the Arctic Ocean. In Johannessen, O.M., Muench, R.D. \& Overland, J.E. (Eds), The Polar Oceans and their Role in Shaping the Global Environment. American Geophysical Union Monograph, 85. Washington, D. C., 33-46.

Schröder-Ritzrau, A. 1995. Aktuopaläontologische Untersuchung zu Verbreitung und Vertikalfluss von Radiolarien sowie ihre räumliche und zeitliche Entwicklung im Europäischen Nordmeer. Berichte aus dem Sonderforschungsbereich 313, 52. Universität zu Kiel, Kiel, Germany, 99pp.

Schröder-Ritzrau, A., Andruleit, H., Jensen, S. et al. 2001. Distribution, export and alteration of fossilizable plankton in the Nordic Seas. In Schäfer, P., Ritzrau, W., Schlüter, M. \& Thiede, J. (Eds), The Northern North Atlantic: A Changing Environment. Springer, Berlin, 81-104.
Sutton, R.T. \& Allen, M.R. 1997. Decadal predictability of North Atlantic sea surface temperature and climate. Nature, 388: 563-567.

Suzuki, N. \& Aita, Y. 2011. Radiolaria: achievements and unresolved issues: taxonomy and cytology. Plankton and Benthos Research, 6: 69-91.

Suzuki, N., Ogane, K., Aita, Y., Sakai, T. \& Lazarus, D. 2009. Re-examination of Ehrenberg's Neogene radiolarian collections and its impact on taxonomic stability. National Museum of Nature and Science Monograph, 40: 87-96.

Swanberg, N.R. \& Bjørklund, K.R. 1986. The radiolarian fauna of western Norwegian fjords: Patterns of abundance in the plankton. Marine Micropaleontology. 11: 231-244.

Takahashi, K. 1983. Radiolaria: Sinking, population, standing stock, and production rate. Marine Micropaleontology, 8: 171-181.

Tan, Z-Y. \& Su, X-H. 1982. Studies on the Radiolaria in sediments of the East China Sea (continental shelf). Studia Marina Sinica 19: 129-216. [In Chinese with English abstract].

Tan, Z-Y. \& Chen, M-H. 1990. Some new revisions of Pyloniidae. Chinese Journal of Oceanology and Limnology, 8: 109-125.

Thornalley, D.J.R., Elderfield, H. \& McCave, I.N. 2009. Holocene oscillations in temperature and salinity of the surface subpolar North Atlantic. Nature, 457: 711-714.

Tibbs, J.F. 1967. On some planktonic Protozoa taken from the track of drift station ARLIS I, 1960-61. Arctic (Journal of the Arctic Institute of North America), 20: 247-254.

Volkmann, R. 2000. Planktic foraminifers in the Fram Strait and the outer Laptev Sea: Modern distribution and ecology. Journal of Foraminiferal Research, 30: 157-176. 